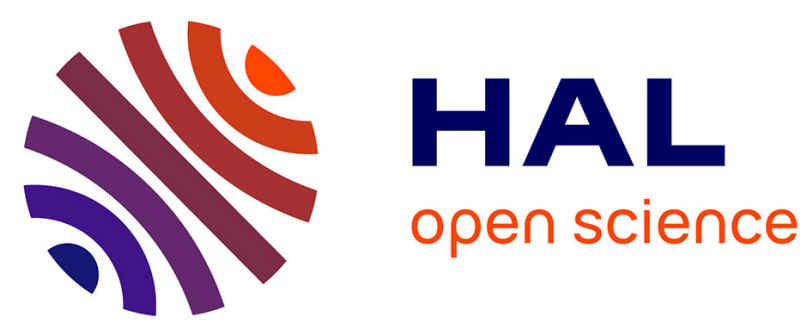

\title{
Tropical mangrove forests as a source of dissolved rare earth elements and yttrium to the ocean
}

Duc Huy Dang, Zhirou Zhang, Wei Wang, Benjamin Oursel, Farid Juillot, Cecile Dupouy, Hugues Lemonnier, Stéphane Mounier

\section{- To cite this version:}

Duc Huy Dang, Zhirou Zhang, Wei Wang, Benjamin Oursel, Farid Juillot, et al.. Tropical mangrove forests as a source of dissolved rare earth elements and yttrium to the ocean. Chemical Geology, 2021, pp.120278. 10.1016/j.chemgeo.2021.120278 . hal-03207854

\section{HAL Id: hal-03207854 \\ https://hal.science/hal-03207854}

Submitted on 26 Apr 2021

HAL is a multi-disciplinary open access archive for the deposit and dissemination of scientific research documents, whether they are published or not. The documents may come from teaching and research institutions in France or abroad, or from public or private research centers.
L'archive ouverte pluridisciplinaire $\mathbf{H A L}$, est destinée au dépôt et à la diffusion de documents scientifiques de niveau recherche, publiés ou non, émanant des établissements d'enseignement et de recherche français ou étrangers, des laboratoires publics ou privés. 
$5 \quad{ }^{1}$ Trent School of the Environment, Trent University, Peterborough, Canada.

$6 \quad{ }^{2}$ Department of Chemistry, Trent University, Peterborough, Canada.

$7 \quad$ 3Aix Marseille Université, Université de Toulon, CNRS, IRD, MIO, Marseille, France

$8 \quad{ }^{4}$ Institut de Minéralogie, de Physique des Matériaux et de Cosmochimie, Sorbonne Université, 9 UMR CNRS 7590, MNHN, ERL IRD 206, Paris, France

10 5Institut de Recherche pour le Developpement (IRD), Centre IRD Noumea, Nouvélle-Caledonie

11 6IFREMER, IRD, Université de la Nouvelle-Calédonie, Université de La Réunion, UMR 92200

12 ENTROPIE, Nouméa, Nouvelle-Calédonie

13 Université de Toulon, Aix Marseille Université, CNRS, IRD, MIO, Toulon, France

14

15 *Corresponding author: huydang@trentu.ca 
Abstract: Rare earth elements (REEs) and Y are commonly used as geochemical proxies for

17 water chemistry, history of the continental crust and provenance studies. At the continent-ocean

18 interface, the estuarine geochemistry of REEs is commonly considered to be driven by a large-

19 scale removal. Consequently, the river-borne flux of dissolved REEs to the marine budget is

20 assumed as a minor fraction. Here, we report a significant release of dissolved REEs, together

21 with a fractionation between light, heavy REEs and Y, in the tropical mangrove estuaries of New

22 Caledonia. These observations were associated with internal recycling within the redox-dynamic

23 mangrove system. The possible contribution of groundwater can be ruled out based on water

24 stable isotopes. These findings imply that tropical mangrove estuaries act as a sizeable source of

25 REEs and Y to the ocean rather than as a buffer zone. We extrapolated our data toward global

26 dissolved fluxes of REEs and Y through the mangroves. This preliminary calculation suggests

27 that the mangrove system supplies $2.6-5 \%$ of global river-borne dissolved $\mathrm{Nd}$, a REE with the

28 most comprehensive mass balance. Therefore, oceanic mass balance budget models may need to

29 consider this atypical system as an input to balance the global distribution of REEs and Y.

30 Keywords: Rare earth elements, yttrium, water stable isotopes, mangrove, estuary. 


\section{Introduction}

32 Over the past decade, rare earth elements (REEs or the lanthanide series), Y and REE isotopes

33 have received significant attention in geochemistry as tracers of the geological history of the

34 continental crust and provenance study (Bayon et al., 2015). In paleoenvironmental studies, REEs

35 are also commonly used as proxies to reconstruct water chemistry and oxygen saturation as per

36 the distinct behaviour of Ce during redox transitions (Auer et al., 2017; Wallace et al., 2017). The

37 fractionation between the light REEs (LREEs), heavy REEs (HREEs) and the non-lanthanide Y

38 can also highlight the mechanisms of particle transport, sediment deposition and even geological

39 features (e.g., iron formation) over the Earth's history (Bayon et al., 2015; Planavsky et al.,

40 2010). More recently, because of the implication of REEs in novel technologies, REE anomalies

41 (increased in concentrations of a specific REE relative to its neighbouring REEs) could also be

42 used as a proxy for emission sources (Dang and Zhang, 2021; Ma et al., 2019; Tepe et al., 2014).

43 However, the environmental chemistry of REEs remains fragmented, mostly regarding their

44 anomalous behaviour across the river-estuarine-coastal water mixing zone where the

45 fractionation between LREEs and HREEs is often associated with the redistribution of REEs

46 among the dissolved and particulate fractions and the formation of stable dissolved complexes

47 (Nozaki et al., 2000; Sholkovitz and Szymczak, 2000; Sholkovitz, 1995). As a consequence, the

48 ocean mass budget of REEs remains unbalanced with missing fluxes at the global scale (Arsouze

49 et al., 2009; Garcia-Solsona and Jeandel, 2020; Pourret and Tuduri, 2017; Tachikawa et al.,

50 2003).

51 The interpretation of estuarine REE behaviour is fundamental to highlight their geochemistry at

52 the continent-ocean interface. One conventional feature derived from decades of investigation on

53 REEs' estuarine geochemistry is that large-scale removal of dissolved REEs (especially LREEs)

54 occurs in the estuarine mixing zone (Elderfield and Greaves, 1982; Lawrence and Kamber, 2006;

55 Nozaki et al., 2000; Pourret and Tuduri, 2017; Sholkovitz, 1995). This phenomenon minimizes

56 the effective continental flux of REEs to the ocean and subsequently affects the marine budget

57 calculations of REEs (Nozaki et al., 2000). Various factors would lead to such extensive removal

58 of REEs. These include planktonic uptake, coprecipitation with ferromanganese oxyhydroxides

59 and salt-induced coagulation of colloids (Hoyle et al., 1983; Nozaki et al., 2000; Sholkovitz and

60 Szymczak, 2000). However, a limited number of publications pointed out a supply of dissolved 
61 REEs in the mid-estuary zones (Lawrence and Kamber, 2006; Nozaki et al., 2000). This REE

62 release could be associated with desorption from terrigenous suspended particles or

63 remineralization in the estuarine system.

64 Moreover, most of the estuarine systems investigated so far for REEs geochemistry were major 65 well-oxygenated riverine systems. However, it has been demonstrated that REEs cycling in 66 marine waters can be impacted by redox variations (Bau et al., 1997). This process is particularly 67 important as it can increase the effective continental REE flux to the oceans through enhanced 68 supply to the water column upon dissolution of REEs-bearing oxyhydroxide phases. Therefore, 69 further insights on REE behaviour across the redox-sensitive estuarine mixing zone are needed to 70 strengthen our understanding of the REE geochemistry at the continent-ocean interface.

71 Tropical mangrove forests are of great interest to investigate these environmental conditions.

72 First, they cover a large surface area $\left(150,000 \mathrm{~km}^{2}\right)$ where complex hydrological processes 73 balance abundant precipitation, surface runoff, and evaporation (Spalding, 2010). Moreover, the 74 combination of elevated and annually constant temperature patterns with high bioavailability of 75 natural organic matter boosts bacterial respiration, promoting hypoxia (Dubuc et al., 2019). To 76 date, very limited studies on REEs focused on this critical ecosystem as it is generally assumed 77 that the mangrove systems act as a buffer zone retaining trace elements and thus contribute a 78 minor input for REEs to the oceans (Marchand et al., 2012).

79 Here, we investigated REE internal cycling within two estuarine mangrove systems in the 80 subtropical region of New Caledonia. We meticulously measured dissolved REEs and Y over a 81 24-hour cycle in mangrove stations during a dry season and the spatial variations across the 82 estuary in a rain season. To track whether additional water masses alter the mixing between the 83 fresh and seawater endmembers, we also measured stable water isotopes $\left(\delta^{18} \mathrm{O}\right.$ and $\left.\delta \mathrm{D}\right)$ to assess 84 the hydrologic regime. We compared the stable water isotopes in these mangrove systems with 85 other river waters collected in southeastern New Caledonia to verify the signature of the 86 freshwater endmembers. Altogether, the data highlights REE behaviour during the estuarine 87 mixing and document the mangrove forest's role on REE cycling at the continent-ocean interface. 88 This dataset will help answer whether the REE continental flux from the tropical mangrove89 dominated estuaries should be included in the REE marine budget. 


\section{Materials and Methods}

\subsection{Study site description}

92 In the Southwest Pacific Ocean, New Caledonia is surrounded by the Coral Sea (Figure 1A,B).

93 The main island "Grande Terre" is $400 \mathrm{~km}$ long and $64 \mathrm{~km}$ wide with a semi-arid tropical climate

94 along the west coast. The whole island is also bordered by a coral reef enclosing a lagoon of over

$9520,000 \mathrm{~km}^{2}$. The rich reef diversity and associated ecosystems were inscribed as a UNESCO

96 World Heritage Site in 2008. On the other hand, most of the island is mountainous with vast

97 ultramafic masses, schists and outcrops of basalt (Lillie and Brothers, 1970). Weathering of the

98 ultramafic rocks' surface led to the formation of thick lateritic regoliths (tens of meters) hosting

99 deposits of transition metallic elements of prime economic importance (Dublet et al., 2014; Noël

100 et al., 2014). Between the lucrative mineral-rich land and the sea of tremendous ecological

101 importance, the mangrove system acts as a buffer zone to filter heavy metals from reaching the

102 reef (Marchand et al., 2012).

103 The hydrological behaviour of the Grande Terre is clearly distinct between the southwestern and

104 northeastern coasts because of the 'rain-shadow' effect across the central massif divide (Terry

105 and Wotling, 2011) (Figure 1B). Accordingly, the southwestern coast (leeward) tends to be drier

106 than the windward northeastern coast. Overall, the hydrologic regime is characterized by high

107 annual variability of rainfall amount and extreme events. Moreover, high and steep watersheds

108 are associated with flash floods and thus rapid water transfer to the lagoons (Desclaux et al.,

109 2018).

110 The Voh-Kone region (Northwest of the Grande Terre, Figure 1B) is an area of great economic

111 and ecological interest. The Koniambo Massif hosts a large mine (Koniambo mine, Figure 1C),

112 one of the largest nickel reserves in New Caledonia. The ore is conveyed to a coastal smelting

113 site (Koniambo Nickel SAS, Figure 1C). Besides, the hydrologic system mainly comprises of

114 two major rivers (Temala and Voh) discharging into the mangroves, then the bays of Chasseloup

115 and Vavouto, respectively. Moreover, the hydrologic system comprises also of relatively smaller

116 streams, such as the Coco River. These small tributaries have their flows significantly reduced

117 during the dry season. 
118 This study focused on the Temala and Coco Rivers (Figure 1C) in the Voh region. The Temala

119 River originates from outside of the Koniambo Massif and discharges into Chasseloup Bay. It is, 120 therefore, considered not impacted by mining activities. On the other hand, the Coco River's 121 sources are in the Koniambo Massif hosting the Koniambo Mine. Along its course toward 122 Vavouto Bay, the Coco River meanders parallelly to the ore conveyor. The Koniambo Nickel 123 SAS smelting site is indeed only ca. $1.2 \mathrm{~km}$ away from the stream (Figure $1 \mathbf{C}$ ). Therefore, it is

124 highly probable that this river is subject to anthropogenic impacts. Besides this contrasted 125 exposition to anthropogenic sources, the natural geological settings of both rivers also differ. The 126 Temala River catchement is made of soils developed on volcano-sedimentary rocks (cherts, 127 basalts), whereas the Coco River catchment is composed of Ni-laterites developed on ultramafic 128 rocks (peridotites) (Merrot et al., 2019).

129 We also investigated river waters (Dumbea, Coulee, Tontouta, Pirogue, Table 1) around Noumea 130 in the Grande Terre's Southeast (Figure 1B) as a reference site for hydrological assessment using 131 salinity and water isotope mixing.

\subsection{Water sampling}

133 We organized multiple sampling trips to investigate the hydrologic regime and REE cycling. The 134 two first sampling campaigns were organized in June 2019 (dry season) and March 2020 (rain 135 season) to collect samples in the Voh-Kone region (Temala and Coco Rivers). We also collected 136 samples in four southeastern rivers (Dumbea, Coulee, Tontouta, Pirogue) in January, March, 137 October and November of 2018. The March samples were collected during and after the Hola 138 tropical cyclone while other samples are collected during the dry season.

139 During a dry season (June 2019), the first campaign aimed for a high-temporal resolution 140 sampling in the mangrove forests (sites C2 and T6, hereafter referred to as "mangrove stations",

141 Figure 1C). For that purpose, two automatic samplers (ISCO) were deployed during high tide (8$1429 \mathrm{~h} \mathrm{AM})$. The samplers were programmed to collect water samples one hour after installation to 143 ensure the resettlement of resuspended sediments during deployment. The first water samples 144 were collected at 9h AM at C2, and 10h AM at T6. Following samples were collected every hour. 145 At the end of the 24-hour automatic sampling cycle, all samples were filtered $(0.22 \mu \mathrm{m}$, cellulose 146 acetate, Sartorius) directly on site. The filtered waters for stable water isotopes were filled to the 
147 top to avoid water-air exchange, while samples for elemental analysis were acidified to $\mathrm{pH}<2$ 148 with ultra-trace $\mathrm{HNO}_{3}$ (Merck). The samples were then immediately shipped by air to Trent 149 University for analysis.

150 In 2020, during the rain season, a series of samples were collected across the salinity gradient 151 along the Temala (T1-T8) and Coco (C1-C5) rivers (hereafter referred to as the "estuarine 152 stations", Figure 1C). An additional sample was collected in the lagoon to serve as a marine

153 endmember (M, Figure 1C). The samples were treated with the same protocol as in 2019 before 154 being shipped to Trent University.

155 All the filters, sampling and storing bottles were previously rinsed with $10 \% \mathrm{HCl}$ and milli-Q 156 water $(18 \mathrm{M} \Omega \mathrm{cm})$ in the laboratory and with river or lagoon water in the field.

\subsection{Water stable isotopes}

Water stable isotopes $\left(\delta^{18} \mathrm{O}\right.$ and $\delta \mathrm{D}$, deuterium) were measured using a Liquid Water Isotope Analyzer (LWIA-24d, Los Gatos Research) at the Water Quality Center (Trent University, Ontario, Canada). The delta notation was calculated relative to the V-SMOW (Vienna-Standard Mean Ocean Water) standard.

$$
\begin{gathered}
\delta^{18} O=\left(\frac{\left(\frac{{ }^{18} O}{{ }^{16} O}\right)_{\text {sample }}}{\left(\frac{{ }^{18} O}{{ }^{16} O}\right)_{V-S M O W}}-1\right) \times 1000(E q .1) \\
\delta D=\left(\frac{\left(\frac{D}{{ }^{1} H}\right)_{\text {sample }}}{\left(\frac{D}{{ }^{1} H}\right)_{V-S M O W}}\right) \times 1000(E q .2)
\end{gathered}
$$

164 Analytical recovery was assessed using two isotopic natural water reference materials (CRMs, 165 Elemental Microanalysis, UK), covering the range of $\delta$ values found in natural waters (Table 166 S1). Averages and standard deviations of each measurement (standards and samples) were 167 calculated based on eight injections (i.e., $\mathrm{n}=8,750 \mathrm{~nL}$ each). We also used ultra-high purity 168 water $(18.2 \mathrm{M} \Omega \mathrm{cm})$ as an in-house standard to bracket every two samples to monitor analytical 
169 drift and eliminate any memory effects. However, no correction was necessary. Analytical 170 recovery of stable water isotopes is reported in Table S1.

\subsection{Elemental analysis}

172 To accurately determine the concentrations of REEs and $\mathrm{Y}$ at the $\mathrm{ng} / \mathrm{L}$ levels in complex 173 environmental matrices (seawater), we have performed a preconcentration step using column chromatography before analysis by Inductively Coupled Plasma Mass Spectrometry (ICP-MS). A full description of the REE column chromatography and ICP-MS analysis were reported elsewhere (Dang and Zhang, 2021; Ma et al., 2019). Briefly, REEs and Y in the filtered water samples were preconcentrated using $0.2 \mathrm{~mL}$ Nobias Chelate-PA1 resin (Hitachi HighTechnologies). An aliquot of $50 \mathrm{~mL}$ of samples buffered at $\mathrm{pH} 6$ was loaded on previously washed and conditioned resin. The seawater matrix was then washed off with $40 \mathrm{~mL} 0.05 \mathrm{M}$ acetate buffer solution ( $\mathrm{pH}=6)$. REEs and $\mathrm{Y}$ were collected by eluting $20 \mathrm{~mL}$ of a $1 \mathrm{M} \mathrm{HNO}_{3}$ solution through the column. This aliquot was collected into a $30 \mathrm{~mL}$ PTFE vessel and completely evaporated on a hotplate at $100^{\circ} \mathrm{C}$. A final $2 \mathrm{~mL}$ of $0.5 \mathrm{M} \mathrm{HNO}_{3}$ was added to retake the REEs and Y.

All acids used to clean and wash the resins were double-distilled trace metal grade. The acetate buffer was also passed through the Nobias column for purification. We also meticulously checked procedural blanks and column recovery in every batch of 10 samples. Procedural blanks were between 0.1 to $29 \mathrm{pg}$ of REEs and Y and significantly less than their mass in natural samples. Several aliquots $(50 \mathrm{~mL})$ of certified reference seawater CASS-6 (National Research Council of Canada, NRCC) were also repeated to test column recovery (Ma et al., 2019). the Trent Water Quality Center. All REEs and Y were analyzed in MS/MS mode with $\mathrm{O}_{2}$ as the reaction cell gas. Detection limits were in the range of 0.1-0.4 ng/L. Although there were no certified reference materials for REEs, we compared the REEs and Y concentrations measured in an NRCC natural water certified reference material (SLRS-6) to the values reported in a European interlaboratory calibration (Yeghicheyan et al., 2019). Excellent recovery was observed; the detailed data are reported in Table $\mathbf{S 2}$.

\subsection{Normalization of REE patterns and calculations of anomalies}


198 A common practice in the scientific community to eliminate the Oddo-Harkins effect and

199 compare samples is to normalize the measured REE concentrations to geological materials (e.g., 200 upper continental crust, shales, chondrite) or offshore seawater (Piper and Bau, 2013). Here, we 201 normalized the measured concentrations of dissolved REEs to Post-Archean Australian Shale 202 (PAAS (McLennan, 2001)) (Goldstein and Jacobsen, 1988; Ma et al., 2019; Piper and Bau, 203 2013). The shale-normalized concentrations are hereafter referred to as REEPAAs.

204 In the current literature, excess or depletion of an REE relative to its neighbouring REEs are 205 referred to as positive or negative anomaly of this element (REE/REE*). Accordingly, the REE 206 anomalies could be determined by several approaches (e.g., arithmetic mean, geometric 207 extrapolations, modelling the shape of PAAS-normalized patterns, third-order polynomial fit). 208 Using all these approaches, Hatje et al. have demonstrated minor variability in the final results 209 (Hatje et al., 2016). Therefore, we calculated Ce, Eu, and Gd anomalies using the following 210 equations (arithmetic mean).

$$
\begin{aligned}
C e / C e & =\frac{2 \times C e_{P A A S}}{L a_{P A A S}+P r_{P A A S}}(E q .3) \\
E u / E u & =\frac{2 \times E u_{P A A S}}{N d_{P A A S}+S m_{P A A S}}(E q .4)
\end{aligned}
$$

$$
\mathrm{Ce} / \mathrm{Ce}=\frac{G d_{P A A S}}{0.33 \times S m_{P A A S}+0.67 \times T b_{P A A S}}(E q .5)
$$

\section{Results and Discussions}

\subsection{Physical-chemical properties}

At both mangrove stations ( $\mathrm{C} 2$ and T6, Figure 1B), $\mathrm{pH}$ values varied within a narrow range (7.8 $\pm 0.1, \mathrm{n}=48$, Table 1 and Figure S1B). Besides, the daily variations in salinity followed a sinusoidal curve, typical of estuarine systems (Figure 2A). This variation pattern is more noticeable at Temala with low tide $(S=26)$ recorded at $4 \mathrm{~h}$ and $16 \mathrm{~h}$, and high tide $(\mathrm{S}=33)$ at $22 \mathrm{~h}$. However, the salinity pattern at Coco is significantly distinct, with two events marked by steep drops at $13 \mathrm{~h}, 19 \mathrm{~h}$ and a third gradual decrease from midnight until $7 \mathrm{~h}$ AM $\left(1^{\text {st }}, 2^{\text {nd }}, 3^{\text {rd }}\right.$ as marked in Figure 2A). The variation range of salinity in Coco is also narrower (29.6 to 34.2) than in Temala (26.0 to 33.0) (Table 1). 
224 Temperature variations also help distinguish the two systems. Water temperatures increased from $225 \quad 16.8^{\circ} \mathrm{C}$ at $11 \mathrm{~h}$ and held constant at ca. $17.5^{\circ} \mathrm{C}$ at Temala (Figure S1A, average of $17.3 \pm 0.2^{\circ} \mathrm{C}, \mathrm{n}$ $226=24$, Table 1). However, the temperature pattern at Coco showed broader variations $\left(15.5^{\circ} \mathrm{C}\right.$ to $227 \quad 16.5^{\circ} \mathrm{C}$, average of $16.1 \pm 0.3^{\circ} \mathrm{C}, \mathrm{n}=24$, Table 1) with temperature drops at $11 \mathrm{~h}$ and $21 \mathrm{~h}($ Figure 228 S1A). Minimums in water temperatures at Coco are lagged by two hours relative to the salinity minimums (13h and 19h, Figure 2A).

230 Across the entire estuaries (estuarine stations), salinities ranged from 0 to 34.9 for the river water 231 and marine endmembers, respectively (Figure 2B). On the other hand, all the river samples 232 collected from the Southeast of New Caledonia are freshwater with a salinity of zero (Figure 233 2C).

\subsection{Stable water isotopes and the hydrologic regime}

235 The $\delta \boldsymbol{D}$ and $\boldsymbol{\delta}^{18} \boldsymbol{O}$ pairing. As the mangrove stations have narrow daily salinity variations (Table 236 1), so too is the range of stable water isotope compositions relative to the whole estuaries (Figure 2372 D-I). At the mangrove stations, the $\delta \mathrm{D}-\delta^{18} \mathrm{O}$ relationship has the equation of $\delta \mathrm{D}=4.3 \times \delta^{18} \mathrm{O}+$ $2385.5(n=40$, Figure S2). The slope of $4.3 \pm 0.6$ is typically lower than other tropical Pacific regions 239 (5.1 to 6.5, Conroy et al. (2014)), and the global seawater average of 7.4 (Rohling, 2007). This 240 indicates a strong influence of the evaporation process in the mangrove during the dry season.

241 Across the estuaries, the $\delta \mathrm{D}-\delta^{18} \mathrm{O}$ relationship of Coco and Temala waters aligns with 242 southeastern rivers with the equation of $\delta \mathrm{D}=4.8 \times \delta^{18} \mathrm{O}-4.6\left(\mathrm{n}=29, \mathrm{r}^{2}=0.9\right.$, Figure S2). The 243 slope $(4.8 \pm 0.3)$ is very similar to the mangrove stations $(4.3 \pm 0.6)$, only the intercepts differ (-

2445.3 across the estuary and +5.5 in the mangrove during the dry season).

245 According to the interpretation of the local evaporation line, as described by Wolfe et al. (2007), 246 local surface waters often plot in linear clusters to the right of the Meteoric Water Line along a 247 slope in the range 4 to 6 . Our observations of consistent slopes ( $4.3 \pm 0.6$ and $4.8 \pm 0.3$ ) fall into 248 this conventional interpretation (Figure S2) considering the Local Meteoric Water Line (LMWL) 249 of $\delta \mathrm{D}=7.1 \times \delta^{18} \mathrm{O}+12.6$ (retrieved from the online isotopes in precipitation calculator, $250 \quad$ www.waterisotopes.org). 
251 To explain the difference in the intercepts (higher values in the dry season than the rain season), 252 we calculated the deuterium excess (d-excess) using the conventional approach: $d$-excess $=\delta \mathrm{D}-$ $2538 \times \delta^{18} \mathrm{O}$. This variable is valuable as it quantifies the deviation of a given dataset from the Global 254 Meteoric Water Line (GMWL) by differential kinetic fractionation effects between D and ${ }^{18} \mathrm{O}$. 255 Such effects are related to humidity, moisture recycling and post-deposition process (Dansgaard, 256 1964). Low d-excess tends to reflect slow evaporation due to high humidity, while high d-excess 257 values indicate fast evaporation due to low humidity (Lee et al., 2003). This interpretation is 258 coherent with our observations as high d-excess values (15.8 $\pm 1.3 \%$ and $15.9 \pm 2.9 \%$ at Coco and 259 Temala, respectively) were observed at the mangrove stations in dry season while low d-excess 260 values were typical of rain season and across the estuaries $(0.4 \pm 5.8 \%$ ) (Table 2$)$.

$261 \quad$ Pairing $\delta \boldsymbol{D}$ and $\boldsymbol{\delta}^{18} \boldsymbol{O}$ with salinity. The linear relationships between $\delta^{18} \mathrm{O}, \delta \mathrm{D}$ and salinity have 262 been used to estimate the stable water isotope composition of a freshwater endmember, defined 263 as the $\delta^{18} \mathrm{O}$ and $\delta \mathrm{D}$ values when salinity equals zero. This extrapolation should be interpreted 264 with careful consideration of the contributions of regional precipitation, river water and runoff. 265 However, it has been demonstrated that the extrapolated $\delta^{18} \mathrm{O}$ and $\delta \mathrm{D}$ of freshwater endmembers 266 in the Great Barrier Reef (NE Australia) reflected the isotope composition of local river water 267 with relatively insignificant contributions of regional precipitation and runoff (Munksgaard et al., 268 2012).

269 Accordingly, $\delta^{18} \mathrm{O}$ and $\delta \mathrm{D}$ values in the samples collected in the mangroves of Coco and Temala 270 varied linearly with salinity (Figure 3 and Table 2). In addition, all linear relationships 271 converged to a common signature of the marine endmember (blue diamond in Figure 3). We 272 extrapolated these linear relationships toward salinity of zero to determine the isotope 273 composition of each river water endmember (Table 2). It is important to note that the 274 interpretation of such relationships often requires a spatial and temporal assessment of the two 275 systems (Conroy et al., 2017). As the samples were collected simultaneously in the dry season, 276 the difference in water isotope composition between the freshwater endmembers at Coco and 277 Temala can thus be only attributed to distinct water sources in each river system.

278 In the mangrove stations, the two linear regression lines are significantly distinct between Coco 279 and Temala, except for a few stations at Temala that fall on the regression line of Coco (encircled 
data, Figure 3B). These data represent the last samples collected during the high tide over the 24-

281 hour series ( $3^{\text {rd }}$ discharge event of the Coco River, Figure 2A). All physical-chemical properties and stable water isotopes of the two rivers overlap during this period (grey zone in Figure 2 A,

283 D, G). This probably reflects a common blackish water mass formed during the high tide.

284 Therefore, we excluded these data from Temala's $\delta$ D-salinity regression because of the lack of more robust proxies to confirm this phenomenon and assuming that it may be minor. The exclusion of these three data did not affect the fact that the water isotope composition is significantly more depleted in the Coco River than Temala during the dry season. This depletion is more noticeable for $\delta \mathrm{D}\left(-72.9 \pm 8.9 \%\right.$ vs. $-36.0 \pm 2.8 \%$, respectively) than $\delta^{18} \mathrm{O}(-9.9 \pm 1.7 \%$ vs. $8.4 \pm 1.2 \%$, respectively) (Table 2).

290 However, across the estuaries and during the rain season, the $\delta \mathrm{D}-\mathrm{S}$ and $\delta^{18} \mathrm{O}-\mathrm{S}$ relationships for 291 both river systems are significantly similar $(\mathrm{p}<0.05)$ and align along with consistent equations $292\left(\delta \mathrm{D}=1.0 \times \mathrm{S}-33.7\right.$ and $\delta^{18} \mathrm{O}=0.2 \times \mathrm{S}-5.2$, Table 2 and Figure 3A $)$. Both the slopes and intercepts 293 are close to the Temala mangrove during the dry season $\left(\delta \mathrm{D}=1.0 \times \mathrm{S}-36.0\right.$ and $\delta^{18} \mathrm{O}=0.2 \times \mathrm{S}-8.4$, 294 Table 2). This observation suggests that the hydrologic regime in the Temala River differs only 295 slightly within seasons with relatively constant water isotope compositions of the river endmember $\left(\delta D_{\text {River }}^{\text {Temala }} \sim-34\right.$ to $-36 \%$ and $\delta^{18} O_{\text {River }}^{\text {Temala }} \sim-5.2$ to $-8.4 \%$ ). These values are close to the four southeastern rivers over an annual cycle (Figure 3A) $\left(\delta D_{\text {River }}^{S E}=-31 \pm 6 \%\right.$ and $\delta^{18} O_{\text {River }}^{\text {SE }}=-5.8 \pm 1.0 \%$, Table 2 ), confirming reasonably consistent $\delta \mathrm{D}-\mathrm{S}$ and $\delta^{18} \mathrm{O}-\mathrm{S}$ relationships and hydrologic regimes of major river systems along the western coast of New

301 It is important to note that the Coco River is a small tributary with a relatively dry riverbed with 302 significantly decreased flow during the dry season. Consequently, the Coco River's isotopic 303 compositions differ substantially during the dry and rain seasons (Table 2) due to less 304 precipitation and enhanced evapotranspiration during the dry season.

305 In summary, the difference in stable water isotope composition between the Coco and Temala 306 rivers is related to the natural effects of a depleted hydrologic reservoir with enhanced 307 evaporation. This effect is naturally more noticeable in small reservoirs during the dry season, 308 such as the Coco River than the major streams (Temala and the four southeastern rivers). Overall, 
we observed a relatively conservative hydrologic system with the mixing of only two water masses: the river freshwater and the marine endmembers. Water isotopic data allow excluding the contribution of a third water mass (e.g., groundwater discharge) in these mangrove-dominated estuarine systems.

\subsection{Rare earth element cycling in the mangrove system.}

314 The PAAS-normalized REE patterns are typical of coastal seawater with a gradual enrichment of 315 heavy REEs relative to light REEs (Hoyle et al., 1983; Nozaki et al., 2000; Piper and Bau, 2013)

316 (Figure 4). Moreover, we observed a depletion of Ce but an enrichment of Eu and Gd relative to 317 their neighbouring REEs that are commonly referred to as anomalies. The anomalies of Ce and 318 Eu were already extensively discussed in the literature. The negative Ce anomaly was shown to 319 develop progressively with increasing salinity as dissolved Ce(III) undergoes continued oxidation 320 to insoluble Ce(IV) across the estuarine zone (Nozaki et al., 2000). The positive Eu anomaly was 321 also reported in the dissolved fractions of various major rivers (Amazon, St Lawrence, Piper and 322 Bau, (2013)) and the clay fractions of river sediments worldwide (Bayon et al., 2015). Several 323 previous studies have recorded positive Eu anomaly in continental materials (e.g., suspended 324 load, atmospheric aerosol and dust, Censi et al., 2004; Goldstein and Jacobsen, 1988). Therefore, 325 the positive Eu anomaly observed in the dissolved loads was interpreted as the result of 326 dissolution from suspended particles and formation of stable dissolved complexes during 327 transport (Nozaki et al., 2000).

328 On the other hand, the Gd anomaly is commonly associated with anthropogenic emissions, such 329 as medical sources (medical resonance imagery) or wastewater (Hatje et al., 2016; Tepe et al., 330 2014). We observed $\mathrm{Gd}$ anomaly ( $\mathrm{Gd} / \mathrm{Gd}^{*}$ up to 3.5) only during the dry season in the Coco 331 river, in the first and second freshwater discharge events (Figure S3 and Figure 2A). We have 332 previously suggested that the $3^{\text {rd }}$ event may be associated with a common brackish water at both 333 Coco and Temala rivers formed during the high tide from $4 \mathrm{~h}$ to $9 \mathrm{~h}$ AM (Figure 2A), which is 334 Gd-anomaly-free (Figure S3D). No Gd anomaly $\left(\mathrm{Gd} / \mathrm{Gd}^{*}=1\right)$ was indeed observed in the 335 marine endmember (blue diamonds, Figure 4 C,D). Given the absence of major medical facilities 336 and considering the low population along the Coco river, a possible medical or wastewater origin 337 for this Gd anomaly can be ruled out. However, the Coco River is associated with the nickel 338 mined lateritic Koniambo regolith where a $13 \mathrm{~km}$ long ore conveyor was built parallel to the river 
and the Koniambo Nickel SAS smelting plant is adjacent to the Coco mangrove (Figure 1C).

340 While there is no precedent study reporting Gd anomaly associated with lateritic ores extraction

341 and processing, the Gd anomaly observed in the Coco river might be associated with those 342 activities.

343 Estuarine mixing behaviors of REEs and $Y$. The REE concentrations in the marine endmembers 344 are typically low; the sum of all REE concentrations ( 2 REEs) approximates $6 \mathrm{ng} / \mathrm{L}$. However, 345 there was a significant difference in REE total concentrations between the two river endmembers, 346 with Temala containing more REEs than Coco ( $\Sigma$ REEs of 24 and $2.6 \mathrm{ng} / \mathrm{L}$, respectively). This 347 trend was also observed at the mangrove stations (Figure S3A). The higher REE concentrations 348 measured in the Temala River waters compared to the Coco River are directly associated with the 349 geology of their watersheds. The Temala watershed is indeed made of soils developed on 350 volcano-sedimentary rocks, whereas the Coco river meanders on lateritic soils developed on 351 ultramafic rocks (Figure 1C) (Merrot et al., 2019). As volcaniclastic bedrock tend to contain 352 higher REE and Y concentrations than the granitic regolith (Chapela Lara et al., 2018), the 353 difference in the watershed's geology could be directly associated with higher REE 354 concentrations in Temala river waters than Coco.

355 Moreover, we did not observe any REEs and Y removal during estuarine mixing between the 356 rivers and the marine endmember, as commonly assumed for REE estuarine geochemistry (see 357 section 1). In fact, we measured very high REE concentrations in the mangrove forest (salinity 358 range of 25-33, see La concentrations in Figure 5A). The high REE (La) concentrations in the 359 mangrove area seem to be conservatively mixed with the freshwater mass $\left(y=0.6 x+3.5, r^{2}=0.97\right)$ 360 and the marine endmember $\left(y=-5.2 x+183, r^{2}=0.84\right)$. This situation was not reported previously. 361 It is commonly assumed that approximately 60-90\% of REEs are removed from the low salinity 362 region of an estuary by flocculation/coagulation of dissolved organic-bound Fe and colloidal 363 materials depleting REEs from the dissolved pool (Lawrence and Kamber, 2006; Pourret and 364 Tuduri, 2017; Sholkovitz and Szymczak, 2000; Sholkovitz, 1995). Minor releases of REEs 365 during an estuary mixing were only reported in the turbid-clear water transition zone $(\mathrm{S}=12-15)$ 366 in the Chao Phraya estuary (Thailand) (Nozaki et al., 2000) and the mid-salinity zone of the 367 Elimbah Creek (Australia) (Lawrence and Kamber, 2006). Such REE release was attributed to 368 several mechanisms, including desorption from suspended particles, coastal erosion, and 
369 mineralization during early diagenesis. In addition, the reductive dissolution of ferromanganese 370 oxides has been shown to significantly release REEs into the porewater, although LREEs tend to 371 sorb back onto the newly formed ferromanganese oxides at the sediment-water interface (Och et 372 al., 2014).

373 Although the La-salinity biplots (Figure 5A) could be interpreted as mixing of three water 374 masses (river, mangrove forest, and marine), stable water isotopes (Figure 3) allow to rule out 375 the possibility of a third water mass in the estuaries of Coco and Temala. Thus, the high La 376 concentrations in the mangrove are instead explained by specific biogeochemical processes 377 leading to the substantial release of dissolved REEs. Given the subtropical weather condition and 378 the high availability of fresh organic matter in the mangrove forest (Noël et al., 2014), it is highly 379 probable that bacterial activity contributes to this REEs solubilization in the sediments porewater 380 (Och et al., 2014). In the mangrove system, the tidal conditions with water pushing up through 381 the porous sediment (seawater circulation cell, Figure 6A) would then favour REE 382 remobilization to the water column. A previous study has demonstrated significant fluxes of 383 REEs from such a seawater circulation through diagenesis-active sediments (i.e., organic matter 384 degradation and reductive dissolution of ferromanganese oxides (Paffrath et al., 2020), Figure 6). 385 Other processes such as passive diffusion fluxes or sediment resuspension events induced by 386 waves and tides (Dang et al., 2020) or bioturbation could also contribute to the REE release 387 towards the water column (Figure 6 C). At a larger scale of the Northwestern Mediterranean Sea, 388 upward diffusion of REEs $(\mathrm{Nd})$ from sediment porewater counts for $30 \%$ of the $\mathrm{Nd}$ marine 389 budget (Garcia-Solsona and Jeandel, 2020). Moreover, given the organic mater-rich surface 390 waters in the mangrove system and the high affinity between REEs and dissolved organic carbon 391 (Davranche et al., 2004; Marsac et al., 2010; Pourret and Davranche, 2013), it is also highly 392 possible that the formation of stable organic complexes could contribute to maintaining REEs in 393 solution in this mid-salinity region (25-33).

394 Fractionation of HREEs/LREEs and elemental ratios. All the water samples collected showed 395 a progressive enrichment of HREEs relative to the PAAS shale (Figure 4). This is consistent 396 with the conventional REE behaviours in the aquatic environment where the fractionation 397 between the dissolved and particulate loads of HREEs and LREEs leads to this characteristic 398 REE curve (Piper and Bau, 2013). Therefore, elemental ratios between representative HREEs and 
399 LREEs (e.g., Er/Nd (Nozaki et al., 2000), Nd/Lu (Sholkovitz, 1995), Ho/Er (Lawrence and

400 Kamber, 2006)) could help determine whether this fractionation occurs in the freshwater

401 endmember or the estuary. As the interpretations using different ratios are very similar, we

402 choose to discuss only the $\mathrm{Er} / \mathrm{Nd}$ (weight ratios).

403 The Er/Nd ratios in both UCC (Rudnick and Gao, 2003) and PAAS (McLennan, 2001)

404 approximate 0.08 , while those in the river endmembers are significantly above this value $(0.2$ and

$405 \quad 0.3$ at Temala and Coco, respectively, Figure 5B). This indicates that the fractionation between

406 HREEs and LREEs occurred in the freshwater system. It is important to note that such

407 fractionation is $\mathrm{pH}$-dependent. At the $\mathrm{pH}$ range observed in Temala and Coco rivers (7.7-7.9,

408 Table 1), REE adsorption on particles is enhanced, leading to significant fractionations by

409 preferential LREE removal (Sholkovitz, 1995). Furthermore, the measured Er/Nd in the estuarine

410 samples varied with salinity along the conservative mixing line of Temala (Figure 5B),

411 suggesting no further fractionation (Lawrence and Kamber, 2006). This is consistent with the

412 occurrence of dissolved organic-REE complexes in the mangrove waters, as previously

413 suggested. Previous studies have demonstrated that the presence of dissolved organic matter

414 significantly reduced REE sorption on ferromanganese oxides and the subsequent fractionation

415 between LREEs and HREEs (Davranche et al., 2005, 2004).

416 On the other hand, a negative departure from the conservative mixing line (i.e., Er/ $\mathrm{Nd}$ ratios

417 decreased) was noticed at the mangrove stations (black arrow in Figure 5B). This indicates a

418 preferential release of LREEs $(\mathrm{Nd})$ relative to the HREEs (Er). This observation is in agreement

419 with the hypothesis that LREEs previously bound to the solid fraction are released toward

420 solution when the oxide phases undergo reductive dissolution (Bau et al., 1997). High REEs

421 concentrations in porewater promote upward diffusion from the sediments by the seawater

422 circulation cell or diffusive flux (Figure 6).

423 Furthermore, variations in the Y/Ho ratios are also of great interest. Although these two elements 424 have similar ionic radii, their electronic configurations differ. Yttrium has no f-electron while Ho 425 has 10 electrons filling up the forbitals (Lawrence and Kamber, 2006). Therefore, the ability to 426 form strong surface and solution complexes using the f orbitals (Byrne and Lee, 1993) drives the 427 fractionation of this pair during weathering, riverine transport or in the marine environment 

surface complexes than Y (Bau et al., 1997; Byrne and Lee, 1993; Lawrence and Kamber, 2006).

430 Therefore, two conditions could lead to Y/Ho fractionation during estuarine mixing. First, 431 coagulation, flocculation and sedimentation of Ho-bearing colloidal particles preferentially 432 remove Ho from solution. Second, as Y tends to form weaker surface complexes than Ho, this 433 fractionation is enhanced by the salt effect (competition for surface sorption sites), which favors 434 Y release from colloidal particles toward solution. Both processes were well documented in the 435 literature to support the increase in the Y/Ho ratio during the estuarine mixing (Figure 6B) 436 (Lawrence and Kamber, 2006).

437 The Y/Ho ratio in the Temala river endmember (28.4) approximates UCC and PAAS (25.3 438 (Rudnick and Gao, 2003) and 27.2 (McLennan, 2001), respectively), indicating that there was no 439 significant fractionation between $\mathrm{Y}$ and the REEs in the Temala river (Figure 5C) (Lawrence and 440 Kamber, 2006). However, in the Coco river endmember, the Y/Ho ratio is significantly lower 441 (18.6). A situation where Y-Ho fractionation leads to lower Y/Ho ratios relative to the UCC is scarcely reported in the literature. While considered a minor process in natural water systems, it was previously reported by Bau et al. in the slightly acidic solutions of low complex-forming capacity of a stream from an abandoned mine (Bau et al., 1995). Interestingly, the Coco River, where this phenomenon is suspected to occur, is connected to the Koniambo mine.

446 In the estuary, we also observed the conventional Y/Ho fractionation (Figure 6B) as the Y/Ho 447 ratios were beyond the conservative mixing lines (Figure 5C). However, the positive departure is 448 even more noticeable in the mangrove forest, with Y/Ho reaching up to 80 (black arrow in

449 Figure 5C). This suggests that additional processes took place in the mangrove forest area, 450 further fractionating this pair. A previous study has suggested that the fractionation between $\mathrm{Y}$ 451 and Ho could be redox driven (Bau et al., 1997). Accordingly, a redox change is expected to 452 occur at the sediment-water interface (Figure 6C) where the upward diffusive flux from 453 mangrove sediments confronts the freshly formed ferromanganese oxyhydroxides. As discussed 454 previously, these reactive surfaces tend to further remove Ho relative to Y. Such preferential 455 removal of Ho increases the Y/Ho ratios as observed in Figure 5C. 
Fluvial fluxes of dissolved constituents in the oceans are essential to balance their marine budget.

458 The current ocean box models for REEs consider major inputs as river-borne dissolved and particulate load, atmospheric dust, groundwater discharge, porewater diffusion and dissolution of reworked sediments (Arsouze et al., 2009; Garcia-Solsona and Jeandel, 2020; Tachikawa et al., $4612003)$.

462 Goldstein and Jacobsen have suggested a simple empirical approach to calculate the dissolved 463 REEs flux $\left(R_{i}^{e f f}\right.$ ) from the continent (Goldstein and Jacobsen, 1988) as detailed in the following 464 equation.

$$
R_{i}^{e f f .}=C_{i}^{R} \times F_{R} \times \phi_{i} \times C F(E q .6)
$$

466 where $C_{i}^{R}$ is the dissolved concentration of an element in the continental endmember $(\mathrm{ng} / \mathrm{L}), \mathrm{F}_{\mathrm{R}}$ is 467 the annual river discharge, $\Phi_{\mathrm{i}}$ is the effective factor, and CF is a correction factor to convert the 468 final units into $\mathrm{kg} / \mathrm{year}$.

469 Here, we applied this calculation to our preliminary dataset to determine whether the fluxes of 470 REEs and Y from the tropical mangrove system could be of interest in the global oceanic budget. 471 Therefore, it is important to note a few assumptions in this simple calculation. First, because of 472 the conservative mixing of REEs and Y between the mangrove system and the seawater (Figure 473 5A), we can assume a full effective factor (i.e., absence of estuarine removal or $\Phi_{i}=1$ ). Second, 474 the local Water Agency (DAVAR, Service de l'eau) monitored the hydrologic regime of the local 475 river systems. According to the most recent report, the monthly discharges of the rivers in the 476 leeward side (southwestern, e.g., Boghen, Poya, Pouembout-Boutana Rivers) of Grand Terre in 4772019 and 2020 average $18.6 \mathrm{~m}^{3} / \mathrm{s}$ in February and $0.6 \mathrm{~m}^{3} / \mathrm{s}$ in May (the month preceding the two 478 sampling campaigns) (DAVAR Service de l'eau, 2020). The variability of the river discharge that 479 could differ Coco and Temala, although not individually determined, could be consisted within 480 the variability of major river systems of the leeward sides. Third, the concentrations of REEs and $481 \quad \mathrm{Y}$ of the mangrove endmember $\left(C_{i}^{R}\right)$ are those of the samples with salinity in the range of 25-34 482 (the mangrove forest, Figure 5A). Finally, the calculated fluxes $\left(R_{i}^{e f f}\right.$. $)$ of dissolved REEs and Y 483 from the mangrove system are reported with standard deviations reflecting the errors propagating 484 through the calculations and variability of all variables. 
485 Accordingly, $R_{i}^{e f f .}$ values of Temala and Coco in the dry and rain seasons are reported in Table

486 S3 while the annual average fluxes are showed in Table 3. The fluxes of REEs and Y are

487 significantly higher in the rain season and dry season (Table S3), as reported in other major

488 estuarine systems (Pourret and Tuduri, 2017). Overall, the annual averages of REE and Y fluxes

489 from the Coco and Temala range from $0.05(\mathrm{Lu})$ to $16.1(\mathrm{Y}) \mathrm{kg}$ per year (Table 3).

490 To extrapolate our data toward a general perspective of the global mangrove system, we first 491 normalized the calculated fluxes to mangrove watershed surface areas $\left(\mathrm{S}_{\mathrm{W}}, \mathrm{km}^{2}\right)$ and the fraction 492 of vegetation coverage $\left(f_{V}\right)$. Equation 7 allows the calculation of area-normalized fluxes of REEs 493 and Y from the two mangrove forests $\left(R_{i}^{S-M F}, \mathrm{~kg} / \mathrm{yr} / \mathrm{km}^{2}\right)$.

494

$$
R_{i}^{S-M F}=\frac{R_{i}^{e f f .}}{S_{W} \times f_{V}}(E q .7)
$$

495 The watershed of the Voh region has a vegetation coverage of approximately $43 \pm 16 \%$ (Taureau 496 et al., 2019), thus $\mathrm{f}_{\mathrm{V}}=0.43$. The surfaces of the Temala and Coco watersheds $\left(\mathrm{S}_{\mathrm{W}}\right)$ approximates $497163 \mathrm{~km}^{2}$ and $42 \mathrm{~km}^{2}$, respectively (FalconBridge NC, 2001). The calculated area-normalized 498 fluxes of REEs and Y range from $1.6 \times 10^{-3}(\mathrm{Lu})$ to $0.4(\mathrm{Y}) \mathrm{kg} / \mathrm{yr} / \mathrm{km}^{2}$.

499 From the $R_{i}^{S-M F}$ values, we attempted an extrapolation to the global surface of mangroves $500 \quad\left(150,000 \mathrm{~km}^{2}\right)($ Spalding, 2010) and thus calculated the global fluxes of dissolved REEs and Y 501 from this unique ecosystem (Table 3). These global fluxes calculated for the mangrove systems 502 could then be compared to the published global river-borne dissolved Nd loads (Arsouze et al., 503 2009; Garcia-Solsona and Jeandel, 2020; Tachikawa et al., 2003). Currently, the Nd oceanic 504 budget is the most comprehensive as extensive studies reported both $\mathrm{Nd}$ concentrations and 505 isotope composition to calibrate its ocean box models. In these models, the river inputs of 506 dissolved $\mathrm{Nd}$ range from 260 to 500 tons per year (or Mg per year) (Rousseau et al., 2015; 507 Tachikawa et al., 2003). Relative to these values, we estimate that the mangrove systems supply $508 \quad 13.3 \pm 5.6$ tons per year of dissolved $\mathrm{Nd}$, representing 2.6-5\% of the total river input of dissolved $509 \mathrm{Nd}$. Compared to other sources (e.g., dust dissolution of 400 tons of $\mathrm{Nd}$ per year, $\mathrm{Nd}$ release from $510 \quad$ suspended particles of 5,700 $\pm 2,600$ ton per year) (Arsouze et al., 2009; Rousseau et al., 2015; 511 Tachikawa et al., 2003), the mangrove systems appear to be a minor source. However, it is 512 important to note that even though this study documents a significant release of REEs and Y 
513 within the mangrove system for the first time, we assess only two small mangrove systems

514 representing $<1 \%$ of the global mangrove surface. Further studies are therefore required to better

515 characterize the contribution of the mangrove system to the global marine budget.

\section{Implications for the role of mangrove on REE cyling and oceanic budgets.}

517 The conventional estuarine REE behaviour often implies a sharp removal of REEs when a 518 riverine water mass enters an estuary. However, our data revealed a significantly release of 519 dissolved REEs and Y (7.3 times for Y, 6.4 times for La and 3.3 times for Lu) in the mangrove 520 system. Although other water masses could supply REEs to the water column (e.g., groundwater 521 discharge (Kim and Kim, 2011)), our stable water isotopes data confirm a sole binary mixing 522 between the fresh and seawater endmembers in the mangrove estuaries of New Caledonia. This 523 release of REEs and Y has thus to be associated only with internal recycling or biogeochemical 524 processes within the mangrove forests. This dataset thus strengthens the hypothesis that tropical 525 mangroves act as a source of dissolved REEs and $\mathrm{Y}$ to the marine system.

526 This finding first redefines the role of tropical mangroves in the cycling of trace elements at the 527 continent-ocean interface. While mangrove forests are often referred to as a buffer zone to filter 528 trace metals from reaching the open sea (Marchand et al., 2012), this assumption might be valid 529 only for the particulate loading. This specific ecosystem produces large amounts of organic 530 matter that is bioavailable for bacterial degradation (Marchand et al., 2012) and thus boosts early 531 diagenesis. These biogeochemical processes lead to the complex recycling of REE-bearing 532 phases. The reductive dissolution of ferromanganese oxides occurs within the subsurface layers 533 of the sediments and is thus responsible for releasing trace elements (Dang et al., 2015, 2014).

534 However, the redox boundary at the seawater-sediment interface leads to forming a thin layer of 535 newly formed Fe- and Mn-oxyhydroxides with large reactive surface areas that efficiently sorb 536 trace elements and thus minimize their upward diffusive flux (Dang et al., 2015; Rigaud et al., 537 2013). Although we could not evaluate the relative amounts of REEs being diffused upward from 538 the sediment porewaters relative to REEs retained at the interface, the diel variation in oxygen 539 concentrations associated with hypoxia events in the mangrove (Dubuc et al., 2019) strongly 540 suggests that the fraction of REEs being retained would be minor regarding the low stability of 541 Fe- and Mn-oxyhydroxides in such redox-dynamic conditions (Bau et al., 1995). 
542 Over the past 30 years, several works aimed to understand and revisit REE behaviour during 543 estuarine mixing and accumulation in sediments (Bayon et al., 2015; Lawrence and Kamber, 544 2006; Sholkovitz and Szymczak, 2000; Sholkovitz, 1995). This first dataset reporting REEs 545 release in a tropical mangrove may provide an important insight into the contribution of 546 mangrove forests to the oceanic budgets and mass balance of REEs and Y. However, these box 547 models remain unbalanced with a significant missing flux (e.g., $800 \mathrm{Mg}$ per year) (Tachikawa et 548 al., 2003). Pourret and Tuduri (2017) recently suggested the continental shelves as a potential 549 resource of REEs to be included in the oceanic mass balance of REEs. Moreover, mangrove is 550 growing in 123 tropical and subtropical countries and covers a total surface of $150,000 \mathrm{~km}^{2}$ 551 (Spalding, 2010). Our simple flux calculation suggests that this atypical system supplies a 552 significant proportion of REEs toward the oceans (2.6-5\% of the global dissolved loading). 553 However, it remains uncertain about the representativity of the Coco and Temala systems of the 554 global mangroves. Therefore, further research on the REE cycling within mangrove systems is 555 needed to determine whether the mangrove estuaries should be considered a significant input in 556 ocean mass budget to balance the global REE distribution.

557 Aknowledgements: The authors thank the Trent University's Internal Operating Grant (\#26090)

558 for financial support to D.D.H. Besides, C.D., F.J., H.L., S.M. and B.O. also acknowledge 559 funding from CRESICA (grant CDEI 2017-2021 - VI-3), CDEI 2017-2021 - VI-3 (grant EC2CO560 Bioeffect/Ecodyn/Dril/MicrobiEn 'TREMOR') and CNRT (grant CSF 9PS2013 561 'DYNAMINE'). We also wish to thank Florence Royer (Ifremer) and Etienne Lopez (Ifremer) 562 for their technical assistance during freshwater sampling in the south, as well as the technical 563 (LAMA, US IMAGO) and administrative staff at IRD Noumea for their help and support relative 564 to field campaigns.

\section{$566 \quad$ References}

567 Arsouze, T., Dutay, J.-C., Lacan, F., Jeandel, C., 2009. Reconstructing the Nd oceanic cycle 568 using a coupled dynamical - biogeochemical model. Biogeosciences Discuss. 6, 5549-5588. 569 doi:10.5194/bgd-6-5549-2009

570 Auer, G., Reuter, M., Hauzenberger, C.A., Piller, W.E., 2017. The impact of transport processes 
on rare earth element patterns in marine authigenic and biogenic phosphates. Geochim. Cosmochim. Acta 203, 140-156. doi:10.1016/j.gca.2017.01.001

573

574

575

576

Bau, M., Dulski, P., Moller, P., 1995. Yttrium and holmium in South Pacific seawater : vertical distribution and possible fractionation mechanisms. Chemie der Erde - Geochemistrymie der Erde 55, 1-15.

Bau, M., Moller, P., Dulski, P., 1997. Yttrium and lanthanides in eastern Mediterranean seawater and their fractionation during redox-cycling. Mar. Chem. 56, 123-131.

Bayon, G., Toucanne, S., Skonieczny, C., André, L., Bermell, S., Cheron, S., Dennielou, B., Etoubleau, J., Freslon, N., Gauchery, T., Germain, Y., Jorry, S.J., Ménot, G., Monin, L., Ponzevera, E., Rouget, M.L., Tachikawa, K., Barrat, J.A., 2015. Rare earth elements and neodymium isotopes in world river sediments revisited. Geochim. Cosmochim. Acta 170, 17-38. doi:10.1016/j.gca.2015.08.001

Byrne, R.H., Lee, J.H., 1993. Comparative yttrium and rare earth element chemistries in seawater. Mar. Chem. doi:10.1016/0304-4203(93)90197-V

Censi, P., Mazzola, S., Sprovieri, M., Bonanno, A., Patti, B., Punturo, R., Spoto, S.E., Saiano, F., Alonzo, G., 2004. Rare earth elements distribution in seawater and suspended particulate of the Central Mediterranean Sea. Chem. Ecol. 20, 323-343. doi:10.1080/02757540410001727954

Chapela Lara, M., Buss, H.L., Pett-Ridge, J.C., 2018. The effects of lithology on trace element and REE behavior during tropical weathering. Chem. Geol. 500, 88-102. doi:10.1016/j.chemgeo.2018.09.024

Conroy, J.L., Cobb, K.M., Lynch-Stieglitz, J., Polissar, P.J., 2014. Constraints on the salinityoxygen isotope relationship in the central tropical Pacific Ocean. Mar. Chem. 161, 26-33. doi:10.1016/j.marchem.2014.02.001

Conroy, J.L., Thompson, D.M., Cobb, K.M., Noone, D., Rea, S., Legrande, A.N., 2017. Spatiotemporal variability in the $\delta 180$-salinity relationship of seawater across the tropical Pacific Ocean. Paleoceanography 32, 484-497. doi:10.1002/2016PA003073 
598

599

600

601

602

603

604

605

606

607

608

609

610

611

612

613

614

615

616

617

618

619

620

621

622

623

624

Dang, D.H., Layglon, N., Ferretto, N., Omanović, D., Mullot, J.-U., Lenoble, V., Mounier, S., Garnier, C., 2020. Kinetic processes of copper and lead remobilization during sediment resuspension of marine polluted sediments. Sci. Total Environ. 698, 134120.

Dang, D.H., Lenoble, V., Durrieu, G., Mullot, J.-U., Mounier, S., Garnier, C., 2014. Sedimentary dynamics of coastal organic matter: An assessment of the porewater size/reactivity model by spectroscopic techniques. Estuar. Coast. Shelf Sci. 151, 100-111.

doi:10.1016/j.ecss.2014.10.002

Dang, D.H., Lenoble, V., Durrieu, G., Omanović, D., Mullot, J.-U., Mounier, S., Garnier, C., 2015. Seasonal variations of coastal sedimentary trace metals cycling: Insight on the effect of manganese and iron (oxy)hydroxides, sulphide and organic matter. Mar. Pollut. Bull. 92, 113-124. doi:10.1016/j.marpolbul.2014.12.048

Dang, D.H., Zhang, Z., 2021. Hazardous motherboards: Evolution of electronic technologies and transition in metals contamination. Environ. Pollut. 268, 115731.

Dansgaard, W., 1964. Stable isotopes in precipitation. Tellus. doi:10.3402/tellusa.v16i4.8993

DAVAR Service de 1'eau, 2020. Synthèse Ressource en Eau.

Davranche, M., Pourret, O., Gruau, G., Dia, A., 2004. Impact of humate complexation on the adsorption of REE onto Fe oxyhydroxide 277, 271-279. doi:10.1016/j.jcis.2004.04.007

Davranche, M., Pourret, O., Gruau, G., Dia, A., Bouhnik-Le Coz, M., 2005. Adsorption of REE (III)-humate complexes onto $\mathrm{MnO} 2$ : Experimental evidence for cerium anomaly and lanthanide tetrad effect suppression. Geochemistry, Geophys. Geosystems 69, 4825-4835. doi:10.1016/j.gca.2005.06.005

Desclaux, T., Lemonnier, H., Genthon, P., Soulard, B., Le Gendre, R., 2018. Suitability of a lumped rainfall-runoff model for flashy tropical watersheds in New Caledonia. Hydrol. Sci. J. 63, 1689-1706. doi:10.1080/02626667.2018.1523613

Dublet, G., Juillot, F., Morin, G., Fritsch, E., Noel, V., Brest, J., Brown, G.E., 2014. XAS evidence for Ni sequestration by siderite in a lateritic Ni-deposit from New Caledonia. Am. Mineral. doi:10.2138/am.2014.4625 
625 Dubuc, A., Baker, R., Marchand, C., Waltham, N.J., Sheaves, M., 2019. Hypoxia in mangroves:

626 Occurrence and impact on valuable tropical fish habitat. Biogeosciences 16, 3959-3976. doi:10.5194/bg-16-3959-2019

628

629

630

631

632

633

634

635

636

637

638

639

640

641

642

643

644

645

646

647

648

649

650

Elderfield, H., Greaves, M.J., 1982. The rare earth elements in seawater. Nature 296, 214-219. doi:10.1038/296214a0

FalconBridge NC, 2001. Projet Koniambo: Carte\# 3. Etude environnementale de base. Carte syntese du milieu bio-physique et du milieu marin.

Garcia-Solsona, E., Jeandel, C., 2020. Balancing Rare Earth Element distributions in the Northwestern Mediterranean Sea. Chem. Geol. 532, 119372. doi:10.1016/j.chemgeo.2019.119372

Goldstein, S.J., Jacobsen, S.B., 1988. Rare earth elements in river waters. Earth Planet. Sci. Lett. 89, 35-47. doi:10.1016/0012-821X(88)90031-3

Hatje, V., Bruland, K.W., Flegal, A.R., 2016. Increases in Anthropogenic Gadolinium Anomalies and Rare Earth Element Concentrations in San Francisco Bay over a 20 Year Record. Environ. Sci. Technol. 50, 4159-4168. doi:10.1021/acs.est.5b04322

Hoyle, J., Elderfield, H., Gledhill, A., Greaves, M., 1983. The behavior of the rare earth elements during mixing of river and sea water. Geochim. Cosmochim. Acta 48, 13-149.

Kim, I., Kim, G., 2011. Large fluxes of rare earth elements through submarine groundwater discharge (SGD) from a volcanic island, Jeju, Korea. Mar. Chem. 127, 12-19. doi:10.1016/j.marchem.2011.07.006

Lawrence, M.G., Kamber, B.S., 2006. The behaviour of the rare earth elements during estuarine mixing-revisited. Mar. Chem. 100, 147-161. doi:10.1016/j.marchem.2005.11.007

Lee, K., Grundstein, A.J., Wenner, D.B., Choi, M., Woo, N., Lee, D., 2003. Climatic controls on the stable isotopic composition of precipitation in Northeast Asia. Clim. Res. 23, 137-148.

Lillie, A.R., Brothers, R.N., 1970. The geology of New Caledonia. New Zeal. J. Geol. Geophys. 13, 145-183. doi:10.1080/00288306.1970.10428210 
Ma, L., Dang, D.H., Wang, Wei, Evans, R.D., Wang, Wen-xiong, 2019. Rare earth elements in the Pearl River Delta of China: Potential impacts of the REE industry on water, suspended particles and oysters. Environ. Pollut. 244, 190-201. doi:10.1016/j.envpol.2018.10.015

Marsac, R., Davranche, M., Gruau, G., Dia, A., 2010. Metal loading effect on rare earth element binding to humic acid: Experimental and modelling evidence. Geochim. Cosmochim. Acta 74, 1749-1761. doi:10.1016/j.gca.2009.12.006

661

662

663

664

665

666

Munksgaard, N.C., Wurster, C.M., Bass, A., Zagorskis, I., Bird, M.I., 2012. First continuous

Marchand, C., Fernandez, J.M., Moreton, B., Landi, L., Lallier-Vergès, E., Baltzer, F., 2012. The partitioning of transitional metals $(\mathrm{Fe}, \mathrm{Mn}, \mathrm{Ni}, \mathrm{Cr})$ in mangrove sediments downstream of a ferralitized ultramafic watershed (New Caledonia). Chem. Geol. doi:10.1016/j.chemgeo.2012.01.018

McLennan, S.M., 2001. Relationships between the trace element composition of sedimentary rocks and upper continental crust. Geochemistry, Geophys. Geosystems 2, 2000 GC000109. doi:10.1038/scientificamerican0983-130

Merrot, P., Juillot, F., Noël, V., Lefebvre, P., Brest, J., Menguy, N., Guigner, J.M., Blondeau, M., Viollier, E., Fernandez, J.M., Moreton, B., Bargar, J.R., Morin, G., 2019. Nickel and iron partitioning between clay minerals, Fe-oxides and Fe-sulfides in lagoon sediments from New Caledonia. Sci. Total Environ. doi:10.1016/j.scitotenv.2019.06.274 shipboard $\delta 180$ and $\delta \mathrm{D}$ measurements in sea water by diffusion sampling-cavity ring-down spectrometry. Environ. Chem. Lett. 10, 301-307. doi:10.1007/s10311-012-0371-5

Noël, V., Marchand, C., Juillot, F., Ona-Nguema, G., Viollier, E., Marakovic, G., Olivi, L., Delbes, L., Gelebart, F., Morin, G., 2014. EXAFS analysis of iron cycling in mangrove sediments downstream a lateritized ultramafic watershed (Vavouto Bay, New Caledonia). Geochim. Cosmochim. Acta 136, 211-228. doi:10.1016/j.gca.2014.03.019

Nozaki, Y., Lerche, D., Alibo, D.S., Snidvongs, A., 2000. The estuarine geochemistry of rare earth elements and indium in the Chao Phraya River, Thailand. Geochim. Cosmochim. Acta 64, 3983-3994. doi:10.1016/S0016-7037(00)00473-7 
678

679

680

681

682

683

684

685

686

687

688

689

690

691

692

693

694

695

696

697

698

699

700

701

702

703

704

Och, L.M., Muller, B., Wichser, A., Ulrich, A., Vologina, E.G., Sturm, M., 2014. Rare earth elements in the sediments of Lake Baikal. Chem. Geol. 376, 61-75. doi:10.1016/j.chemgeo.2014.03.018

Paffrath, R., Pahnke, K., Behrens, M., Reckhardt, A., Ehlert, C., Schnetger, B., Brumsack, H.-J., 2020. Rare Earth Element Behavior in a Sandy Subterranean Estuary of the Southern North Sea. Front. Mar. Sci. 7, 424. doi:10.3389/fmars.2020.00424

Piper, D.Z., Bau, M., 2013. Normalized Rare Earth Elements in Water, Sediments , and Wine : Identifying Sources and Environmental Redox Conditions. Am. J. Anal. Chem. 4, 69-83. doi:10.4236/ajac.2013.410A1009

Planavsky, N., Bekker, A., Rouxel, O.J., Kamber, B., Hofmann, A., Knudsen, A., Lyons, T.W., 2010. Rare Earth Element and yttrium compositions of Archean and Paleoproterozoic Fe formations revisited: New perspectives on the significance and mechanisms of deposition. Geochim. Cosmochim. Acta 74, 6387-6405. doi:10.1016/j.gca.2010.07.021

Pourret, O., Davranche, M., 2013. Rare earth element sorption onto hydrous manganese oxide: A modeling study. J. Colloid Interface Sci. 395, 18-23. doi:10.1016/j.jcis.2012.11.054

Pourret, O., Tuduri, J., 2017. Continental shelves as potential resource of rare earth elements. Sci. Rep. 7, 1-6. doi:10.1038/s41598-017-06380-z

Rigaud, S., Radakovitch, O., Couture, R.-M., Deflandre, B., Cossa, D., Garnier, C., Garnier, J.M., 2013. Mobility and fluxes of trace elements and nutrients at the sediment-water interface of a lagoon under contrasting water column oxygenation conditions. Appl. Geochemistry 31, 35-51. doi:10.1016/j.apgeochem.2012.12.003

Rohling, E.J., 2007. Progress in paleosalinity: Overview and presentation of a new approach. Paleoceanography. doi:10.1029/2007PA001437

Rousseau, T.C.C., Sonke, J.E., Chmeleff, J., Van Beek, P., Souhaut, M., Boaventura, G., Seyler, P., Jeandel, C., 2015. Rapid neodymium release to marine waters from lithogenic sediments in the Amazon estuary. Nat. Commun. 6. doi:10.1038/ncomms 8592

Rudnick, R., Gao, S., 2003. Composition of the continental crust, in: Turekian, K.K., Holland, 
706

707

708

709

710

711

712

713

714

715

716

717

718

719

720

721

722

723

724

725

726

727

728

729

730

731

Sholkovitz, E., Szymczak, R., 2000. The estuarine chemistry of rare earth elements: Comparison of the Amazon, Fly, Sepik and the Gulf of Papua systems. Earth Planet. Sci. Lett. 179, 299309. doi:10.1016/S0012-821X(00)00112-6

Sholkovitz, E.R., 1995. The aquatic chemistry of rare earth elements in rivers and estuaries. Aquat. Geochemistry 1, 1-34. doi:10.1007/BF01025229

Spalding, M., 2010. World Atlas of Mangroves, World Atlas of Mangroves. doi: $10.4324 / 9781849776608$

Tachikawa, K., Athias, V., Jeandel, C., 2003. Neodymium budget in the modern ocean and paleooceanographic implications. J. Geophys. Res. Ocean. 108, 1-13. doi:10.1029/1999jc000285

Taureau, F., Robin, M., Proisy, C., Fromard, F., Imbert, D., Debaine, F., 2019. Mapping the mangrove forest canopy using spectral unmixing of very high spatial resolution satellite images. Remote Sens. 11. doi:10.3390/rs11030367

Tepe, N., Romero, M., Bau, M., 2014. High-technology metals as emerging contaminants: Strong increase of anthropogenic gadolinium levels in tap water of Berlin, Germany, from 2009 to 2012. Appl. Geochemistry 45, 191-197. doi:10.1016/j.apgeochem.2014.04.006

Terry, J.P., Wotling, G., 2011. Rain-shadow hydrology: Influences on river flows and flood magnitudes across the central massif divide of La Grande Terre Island, New Caledonia. J. Hydrol. 404, 77-86. doi:10.1016/j.jhydrol.2011.04.022

Wallace, M.W., Hood, A., Shuster, A., Greig, A., Planavsky, N.J., Reed, C.P., 2017. Oxygenation history of the Neoproterozoic to early Phanerozoic and the rise of land plants. Earth Planet. Sci. Lett. 466, 12-19. doi:10.1016/j.eps1.2017.02.046

Wolfe, B.B., Karst-Riddoch, T.L., Hall, R., Edwards, T., English, M., Palmini, R., Mcgowan, S., Leavitt, P., Vardy, S., 2007. Classification of hydrological regimes of northern floodplain basins (Peace-Athabasca Delta, Canada) from analysis of stable isotopes $(\mathrm{d} 18 \mathrm{O}, \mathrm{d} 2 \mathrm{H})$ and water chemistry. Hydrol. Process. 21, 151-168. doi:10.1002/hyp.6229 Classification

Yeghicheyan, D., Aubert, D., Bouhnik-Le Coz, M., Chmeleff, J., Delpoux, S., Djouraev, I., 
Granier, G., Lacan, F., Piro, J.L., Rousseau, T., Cloquet, C., Marquet, A., Menniti, C., Pradoux, C., Freydier, R., Vieira da Silva-Filho, E., Suchorski, K., 2019. A New Interlaboratory Characterisation of Silicon, Rare Earth Elements and Twenty-Two Other Trace Element Concentrations in the Natural River Water Certified Reference Material SLRS-6 (NRC-CNRC). Geostand. Geoanalytical Res. 43, 475-496. doi:10.1111/ggr.12268

(2) Auer, G.; Reuter, M.; Hauzenberger, C. A.; Piller, W. E. The Impact of Transport Processes on Rare Earth Element Patterns in Marine Authigenic and Biogenic Phosphates. Geochim. Cosmochim. Acta 2017, 203, 140-156. https://doi.org/10.1016/j.gca.2017.01.001.

(3) Wallace, M. W.; Hood, A.; Shuster, A.; Greig, A.; Planavsky, N. J.; Reed, C. P. Oxygenation History of the Neoproterozoic to Early Phanerozoic and the Rise of Land Plants. Earth Planet. Sci. Lett. 2017, 466, 12-19. https://doi.org/10.1016/j.epsl.2017.02.046.

(4) Planavsky, N.; Bekker, A.; Rouxel, O. J.; Kamber, B.; Hofmann, A.; Knudsen, A.; Lyons, T. W. Rare Earth Element and Yttrium Compositions of Archean and Paleoproterozoic Fe Formations Revisited: New Perspectives on the Significance and Mechanisms of Deposition. Geochim. Cosmochim. Acta 2010, 74 (22), 6387-6405. https://doi.org/10.1016/j.gca.2010.07.021.

(5) Tepe, N.; Romero, M.; Bau, M. High-Technology Metals as Emerging Contaminants: Strong Increase of Anthropogenic Gadolinium Levels in Tap Water of Berlin, Germany, from 2009 to 2012. Appl. Geochemistry 2014, 45, 191-197. https://doi.org/10.1016/j.apgeochem.2014.04.006.

(6) Dang, D. H.; Zhang, Z. Hazardous Motherboards: Evolution of Electronic Technologies and Transition in Metals Contamination. Environ. Pollut. 2021, 268, 115731.

(7) Ma, L.; Dang, D. H.; Wang, W.; Evans, R. D.; Wang, W. Rare Earth Elements in the Pearl River Delta of China: Potential Impacts of the REE Industry on Water, Suspended Particles and Oysters. Environ. Pollut. 2019, 244, 190-201. 
https://doi.org/10.1016/j.envpol.2018.10.015.

(8) Sholkovitz, E. R. The Aquatic Chemistry of Rare Earth Elements in Rivers and Estuaries. Aquat. Geochemistry 1995, 1 (1), 1-34. https://doi.org/10.1007/BF01025229.

(9) Sholkovitz, E.; Szymczak, R. The Estuarine Chemistry of Rare Earth Elements: Comparison of the Amazon, Fly, Sepik and the Gulf of Papua Systems. Earth Planet. Sci. Lett. 2000, 179 (2), 299-309. https://doi.org/10.1016/S0012-821X(00)00112-6.

(10) Nozaki, Y.; Lerche, D.; Alibo, D. S.; Snidvongs, A. The Estuarine Geochemistry of Rare Earth Elements and Indium in the Chao Phraya River, Thailand. Geochim. Cosmochim. Acta 2000, 64 (23), 3983-3994. https://doi.org/10.1016/S0016-7037(00)00473-7.

(11) Pourret, O.; Tuduri, J. Continental Shelves as Potential Resource of Rare Earth Elements.

(12) Elderfield, H.; Greaves, M. J. The Rare Earth Elements in Seawater. Nature 1982, 296

(13) Lawrence, M. G.; Kamber, B. S. The Behaviour of the Rare Earth Elements during

(14) Hoyle, J.; Elderfield, H.; Gledhill, A.; Greaves, M. The Behavior of the Rare Earth Elements during Mixing of River and Sea Water. Geochim. Cosmochim. Acta 1983, 48 (0016-7037), 13-149.

(15) Bau, M.; Moller, P.; Dulski, P. Yttrium and Lanthanides in Eastern Mediterranean Seawater and Their Fractionation during Redox-Cycling. Mar. Chem. 1997, 56, 123-131.

(16) Spalding, M. World Atlas of Mangroves; 2010. https://doi.org/10.4324/9781849776608.

(17) Dubuc, A.; Baker, R.; Marchand, C.; Waltham, N. J.; Sheaves, M. Hypoxia in Mangroves: Occurrence and Impact on Valuable Tropical Fish Habitat. Biogeosciences 2019, 16 (20), 3959-3976. https://doi.org/10.5194/bg-16-3959-2019.

(18) Marchand, C.; Fernandez, J. M.; Moreton, B.; Landi, L.; Lallier-Vergès, E.; Baltzer, F. 
The Partitioning of Transitional Metals (Fe, Mn, Ni, Cr) in Mangrove Sediments Downstream of a Ferralitized Ultramafic Watershed (New Caledonia). Chem. Geol. 2012. https://doi.org/10.1016/j.chemgeo.2012.01.018.

(19) Lillie, A. R.; Brothers, R. N. The Geology of New Caledonia. New Zeal. J. Geol. Geophys. 1970, 13 (1), 145-183. https://doi.org/10.1080/00288306.1970.10428210.

(20) Dublet, G.; Juillot, F.; Morin, G.; Fritsch, E.; Noel, V.; Brest, J.; Brown, G. E. XAS Evidence for Ni Sequestration by Siderite in a Lateritic Ni-Deposit from New Caledonia. Am. Mineral. 2014. https://doi.org/10.2138/am.2014.4625.

(21) Noël, V.; Marchand, C.; Juillot, F.; Ona-Nguema, G.; Viollier, E.; Marakovic, G.; Olivi, 795 L.; Delbes, L.; Gelebart, F.; Morin, G. EXAFS Analysis of Iron Cycling in Mangrove Sediments Downstream a Lateritized Ultramafic Watershed (Vavouto Bay, New Caledonia). Geochim. Cosmochim. Acta 2014, 136, 211-228. https://doi.org/10.1016/j.gca.2014.03.019.

(22) Fritsch, E.; Juillot, F.; Dublet, G.; Fonteneau, L.; Fandeur, D.; Martin, E.; Caner, L.; Auzende, A.-L.; Grauby, O.; Beaufort, D. An Alternative Model for the Formation of Hydrous Mg/Ni Layer Silicates ('deweylite'/'garnierite') in Faulted Peridotites of New Caledonia: I. Texture and Mineralogy of a Paragenetic Succession of Silicate Infillings. Eur. J. Mineral. 2016, 28 (2), 295-311. https://doi.org/10.1127/ejm/2015/0027-2503.

(23) Yeghicheyan, D.; Aubert, D.; Bouhnik-Le Coz, M.; Chmeleff, J.; Delpoux, S.; Djouraev, I.; Granier, G.; Lacan, F.; Piro, J. L.; Rousseau, T.; et al. A New Interlaboratory Characterisation of Silicon, Rare Earth Elements and Twenty-Two Other Trace Element Concentrations in the Natural River Water Certified Reference Material SLRS-6 (NRCCNRC). Geostand. Geoanalytical Res. 2019, 43 (3), 475-496. https://doi.org/10.1111/ggr.12268.

(24) Piper, D. Z.; Bau, M. Normalized Rare Earth Elements in Water, Sediments, and Wine : Identifying Sources and Environmental Redox Conditions. Am. J. Anal. Chem. 2013, 4, 69-83. https://doi.org/10.4236/ajac.2013.410A1009.

(25) McLennan, S. M. Relationships between the Trace Element Composition of Sedimentary 
Rocks and Upper Continental Crust. Geochemistry, Geophys. Geosystems 2001, 2, 2000GC000109. https://doi.org/10.1038/scientificamerican0983-130.

(26) Goldstein, S. J.; Jacobsen, S. B. Rare Earth Elements in River Waters. Earth Planet. Sci. Lett. 1988, 89 (1), 35-47. https://doi.org/10.1016/0012-821X(88)90031-3.

(27) Hatje, V.; Bruland, K. W.; Flegal, A. R. Increases in Anthropogenic Gadolinium Anomalies and Rare Earth Element Concentrations in San Francisco Bay over a 20 Year Record. Environ. Sci. Technol. 2016, 50 (8), 4159-4168. https://doi.org/10.1021/acs.est.5b04322.

(28) Conroy, J. L.; Cobb, K. M.; Lynch-Stieglitz, J.; Polissar, P. J. Constraints on the SalinityOxygen Isotope Relationship in the Central Tropical Pacific Ocean. Mar. Chem. 2014, 161, 26-33. https://doi.org/10.1016/j.marchem.2014.02.001.

(29) Rohling, E. J. Progress in Paleosalinity: Overview and Presentation of a New Approach. Paleoceanography. 2007. https://doi.org/10.1029/2007PA001437.

(30) Wolfe, B. B.; Karst-Riddoch, T. L.; Hall, R.; Edwards, T.; English, M.; Palmini, R.; Mcgowan, S.; Leavitt, P.; Vardy, S. Classification of Hydrological Regimes of Northern Floodplain Basins (Peace-Athabasca Delta, Canada) from Analysis of Stable Isotopes (D18O, D2H) and Water Chemistry. Hydrol. Process. 2007, 21, 151-168. https://doi.org/10.1002/hyp.6229 Classification.

(31) Dansgaard, W. Stable Isotopes in Precipitation. Tellus 1964. https://doi.org/10.3402/tellusa.v16i4.8993.

(32) Lee, K.; Grundstein, A. J.; Wenner, D. B.; Choi, M.; Woo, N.; Lee, D. Climatic Controls on the Stable Isotopic Composition of Precipitation in Northeast Asia. Clim. Res. 2003, 23, $137-148$.

(33) Munksgaard, N. C.; Wurster, C. M.; Bass, A.; Zagorskis, I.; Bird, M. I. First Continuous Shipboard $\delta 180$ and $\Delta \mathrm{D}$ Measurements in Sea Water by Diffusion Sampling-Cavity Ring-down Spectrometry. Environ. Chem. Lett. 2012, 10 (3), 301-307. https://doi.org/10.1007/s10311-012-0371-5. 
(34) Conroy, J. L.; Thompson, D. M.; Cobb, K. M.; Noone, D.; Rea, S.; Legrande, A. N. Spatiotemporal Variability in the $\Delta 180$-Salinity Relationship of Seawater across the Tropical Pacific Ocean. Paleoceanography 2017, 32 (5), 484-497.

(35) Censi, P.; Mazzola, S.; Sprovieri, M.; Bonanno, A.; Patti, B.; Punturo, R.; Spoto, S. E.; Saiano, F.; Alonzo, G. Rare Earth Elements Distribution in Seawater and Suspended

(36) Och, L. M.; Muller, B.; Wichser, A.; Ulrich, A.; Vologina, E. G.; Sturm, M. Rare Earth

Particulate of the Central Mediterranean Sea. Chem. Ecol. 2004, 20 (5), 323-343. https://doi.org/10.1080/02757540410001727954. Elements in the Sediments of Lake Baikal. Chem. Geol. 2014, 376, 61-75. https://doi.org/10.1016/j.chemgeo.2014.03.018.

(37) Paffrath, R.; Pahnke, K.; Behrens, M.; Reckhardt, A.; Ehlert, C.; Schnetger, B.; Brumsack, H.-J. Rare Earth Element Behavior in a Sandy Subterranean Estuary of the Southern North Sea. Front. Mar. Sci. 2020, 7, 424. https://doi.org/10.3389/fmars.2020.00424.

(38) Dang, D. H.; Layglon, N.; Ferretto, N.; Omanović, D.; Mullot, J.-U.; Lenoble, V.; Mounier, S.; Garnier, C. Kinetic Processes of Copper and Lead Remobilization during Sediment Resuspension of Marine Polluted Sediments. Sci. Total Environ. 2020, 698, 134120.

(39) Garcia-Solsona, E.; Jeandel, C. Balancing Rare Earth Element Distributions in the Northwestern Mediterranean Sea. Chem. Geol. 2020, 532 (June 2019), 119372. https://doi.org/10.1016/j.chemgeo.2019.119372.

(40) Marsac, R.; Davranche, M.; Gruau, G.; Dia, A. Metal Loading Effect on Rare Earth Element Binding to Humic Acid: Experimental and Modelling Evidence. Geochim. Cosmochim. Acta 2010, 74 (6), 1749-1761. https://doi.org/10.1016/j.gca.2009.12.006.

(41) Davranche, M.; Pourret, O.; Gruau, G.; Dia, A. Impact of Humate Complexation on the Adsorption of REE onto Fe Oxyhydroxide. 2004, 277, 271-279.

https://doi.org/10.1016/j.jcis.2004.04.007. 
868

869

870

871

872

873

874

875

876

877

878

879

880

881

882

883

884

885

886

887

888

889

890

891

892

893

894

(42) Pourret, O.; Davranche, M. Rare Earth Element Sorption onto Hydrous Manganese Oxide: A Modeling Study. J. Colloid Interface Sci. 2013, 395 (1), 18-23. https://doi.org/10.1016/j.jcis.2012.11.054.

(43) Rudnick, R.; Gao, S. Composition of the Continental Crust. In Treatise on geochemistry; Turekian, K. K., Holland, H. D., Eds.; Elsevier Ltd, 2003; Vol. 1, pp 1-64.

(44) Davranche, M.; Pourret, O.; Gruau, G.; Dia, A.; Bouhnik-Le Coz, M. Adsorption of REE (III)-Humate Complexes onto MnO2: Experimental Evidence for Cerium Anomaly and Lanthanide Tetrad Effect Suppression. Geochemistry, Geophys. Geosystems 2005, 69 (20), 4825-4835. https://doi.org/10.1016/j.gca.2005.06.005.

(45) Byrne, R. H.; Lee, J. H. Comparative Yttrium and Rare Earth Element Chemistries in Seawater. Mar. Chem. 1993. https://doi.org/10.1016/0304-4203(93)90197-V.

(46) Bau, M.; Dulski, P.; Moller, P. Yttrium and Holmium in South Pacific Seawater : Vertical Distribution and Possible Fractionation Mechanisms. Chemie der Erde - Geochemistrymie der Erde 1995, 55, 1-15.

(47) Dang, D. H.; Lenoble, V.; Durrieu, G.; Omanović, D.; Mullot, J.-U.; Mounier, S.; Garnier, C. Seasonal Variations of Coastal Sedimentary Trace Metals Cycling: Insight on the Effect of Manganese and Iron (Oxy)Hydroxides, Sulphide and Organic Matter. Mar. Pollut. Bull. 2015, 92, 113-124. https://doi.org/10.1016/j.marpolbul.2014.12.048.

(48) Arsouze, T.; Dutay, J.-C.; Lacan, F.; Jeandel, C. Reconstructing the Nd Oceanic Cycle Using a Coupled Dynamical - Biogeochemical Model. Biogeosciences Discuss. 2009, 6 (3), 5549-5588. https://doi.org/10.5194/bgd-6-5549-2009.

(49) Tachikawa, K.; Athias, V.; Jeandel, C. Neodymium Budget in the Modern Ocean and Paleo-Oceanographic Implications. J. Geophys. Res. Ocean. 2003, 108 (8), 1-13. https://doi.org/10.1029/1999jc000285.

(50) DAVAR Service de l'eau. Synthèse Ressource En Eau; 2019; Vol. Décembre.

(51) Taureau, F.; Robin, M.; Proisy, C.; Fromard, F.; Imbert, D.; Debaine, F. Mapping the Mangrove Forest Canopy Using Spectral Unmixing of Very High Spatial Resolution 
Satellite Images. Remote Sens. 2019, 11 (3). https://doi.org/10.3390/rs11030367.

896

897

898

899

900

901

902

903

904

905

906

907

908

909

910

911

912

913
(52) FalconBridge NC. Projet Koniambo: Carte\# 3. Étude Environnementale de Base. Carte Synthèse Du Milieu Bio-Physique et Du Milieu Marin; 2001.

(53) Rousseau, T. C. C.; Sonke, J. E.; Chmeleff, J.; Van Beek, P.; Souhaut, M.; Boaventura, G.; Seyler, P.; Jeandel, C. Rapid Neodymium Release to Marine Waters from Lithogenic Sediments in the Amazon Estuary. Nat. Commun. 2015, 6 (May). https://doi.org/10.1038/ncomms8592.

(54) Kim, I.; Kim, G. Large Fluxes of Rare Earth Elements through Submarine Groundwater Discharge (SGD) from a Volcanic Island, Jeju, Korea. Mar. Chem. 2011, 127 (1-4), 1219. https://doi.org/10.1016/j.marchem.2011.07.006.

(55) Dang, D. H.; Lenoble, V.; Durrieu, G.; Mullot, J.-U.; Mounier, S.; Garnier, C. Sedimentary Dynamics of Coastal Organic Matter: An Assessment of the Porewater Size/Reactivity Model by Spectroscopic Techniques. Estuar. Coast. Shelf Sci. 2014, 151, 100-111. https://doi.org/10.1016/j.ecss.2014.10.002.

(56) Rigaud, S.; Radakovitch, O.; Couture, R.-M.; Deflandre, B.; Cossa, D.; Garnier, C.; Garnier, J.-M. Mobility and Fluxes of Trace Elements and Nutrients at the SedimentWater Interface of a Lagoon under Contrasting Water Column Oxygenation Conditions. Appl. Geochemistry 2013, 31, 35-51. https://doi.org/10.1016/j.apgeochem.2012.12.003. 


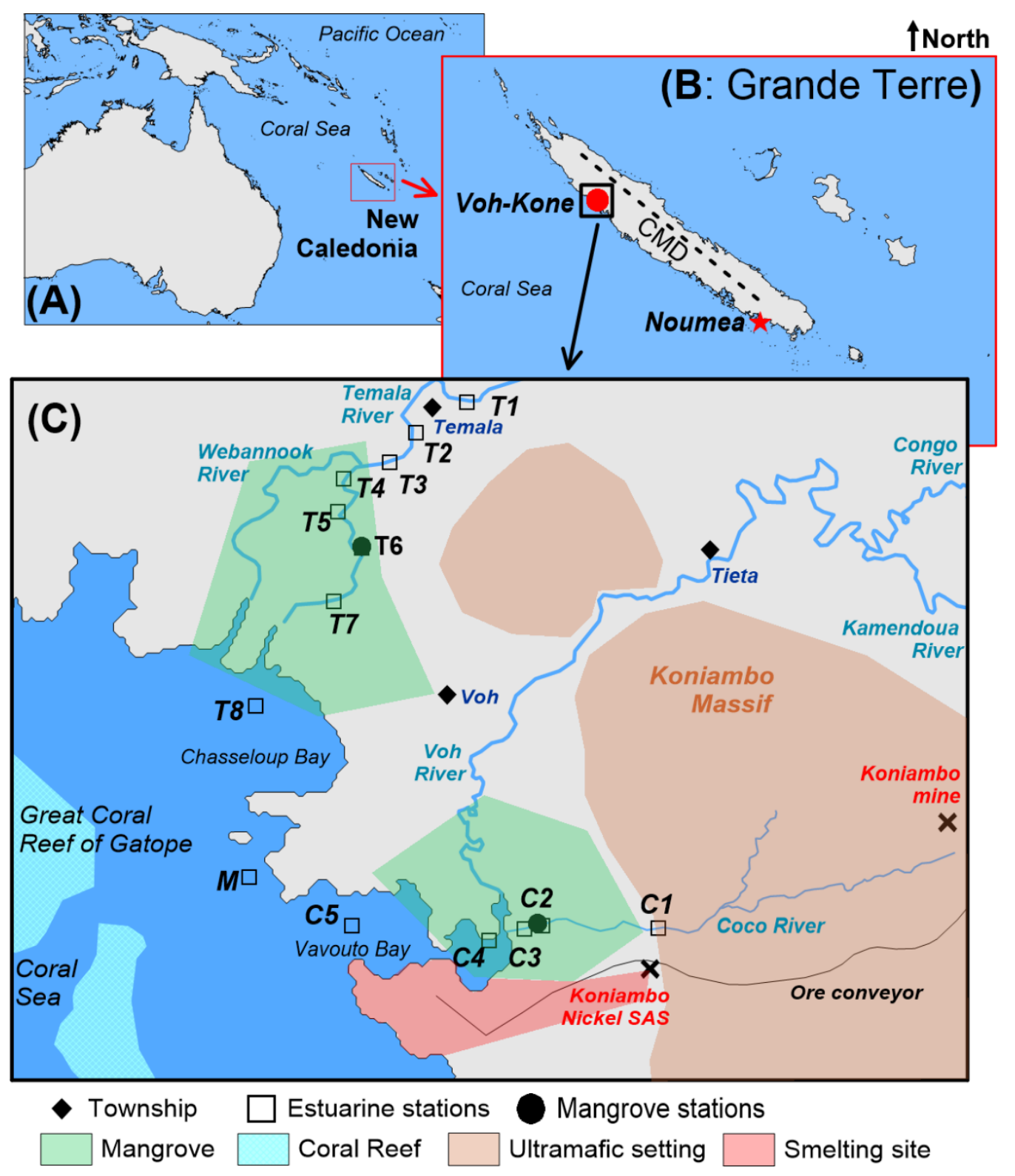

Figure 1: Map of New Caledonia (A), the two regions under investigation: Voh-Kone region (red circle) and four rivers in the Southeast of Grande Terre (red star), around Noumea (B), and a zoom into the Voh-Kone region with sampling locations (C). The position of the CMD (Central Massive Divide) in B is approximative. The southwestern basins of the CMD are considered leeward while the northeastern are windward. See text for more details on the study sites. 


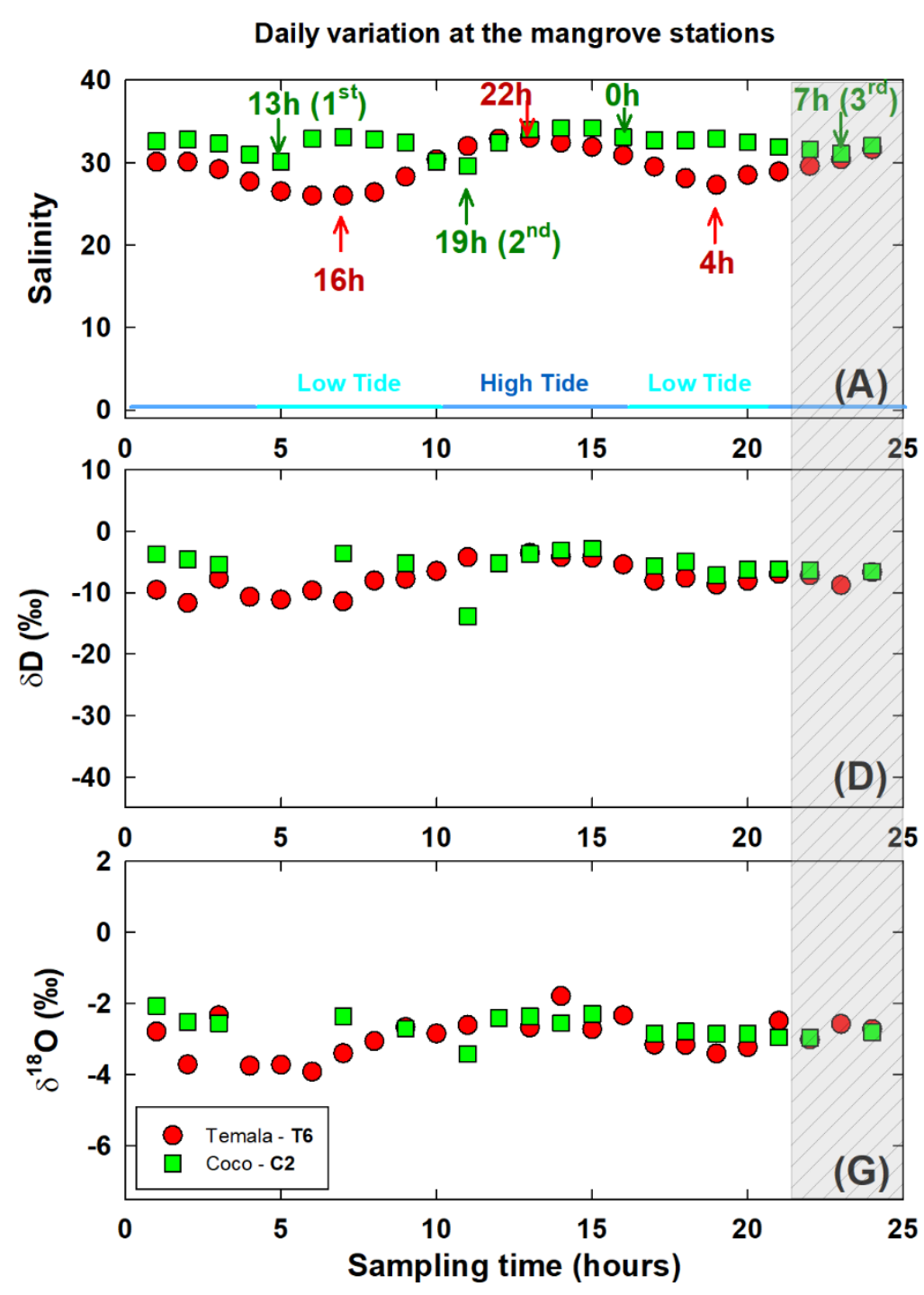

Estuarine stations

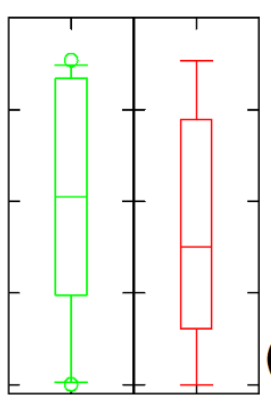

(B)

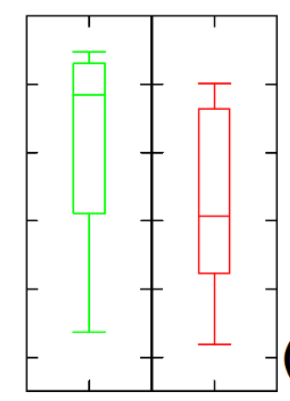

(E)

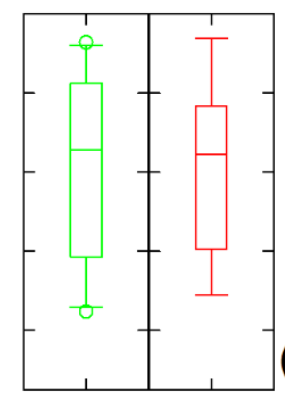

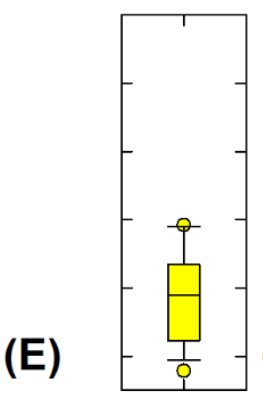

(F)

Annual variations

southeastern rivers

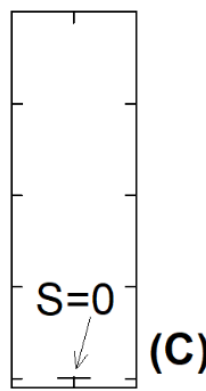

(C)

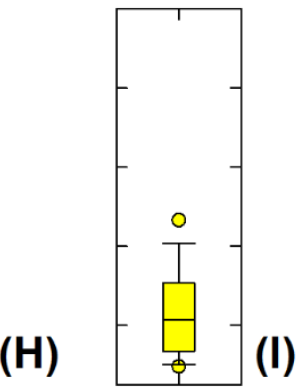

Figure 2: Variations in salinity, $\delta \mathrm{D}$ and $\delta^{18} \mathrm{O}$ in waters collected from the Temala (red symbols) and Coco (green symbols) Rivers of the Voh-Kone regions and four rivers of the Southeast (yellow boxes). Left panels (A, D, G) show the daily variations recorded within 24 hours in the mangrove forest (stations T6 and C2). The arabic numbers $\left(1^{\text {st }}, 2^{\text {nd }}, 3^{\text {rd }}\right)$ indicates the three events where freshwaters were discharged from the Coco river toward the lagoon. The greyed zone shows the last samples collected of the 24-hour series during high tide where all physicalchemical properties and stable water isotopes of the two rivers overlaps. Those data are excluded from the $\delta \mathrm{D}$-salinity regresssion of Temala River as justified in text. Middle box plots $(\mathrm{B}, \mathrm{E}, \mathrm{H})$ summarize the spatial variations of Temala and Coco estuaries. The right box plots $(\mathrm{C}, \mathrm{F}, \mathrm{I})$ show the annual variations of the four rivers in the Southeast of New Caledonia. For all box plots, the horinzonal lines in boxes show median values while box boundaries indicate the $25^{\text {th }}$ and $75^{\text {th }}$ percentiles. The whiskers demark the $10^{\text {th }}$ and $90^{\text {th }}$ percentiles and scatters are values of the $5^{\text {th }}$ and $95^{\text {th }}$ percentile range. 


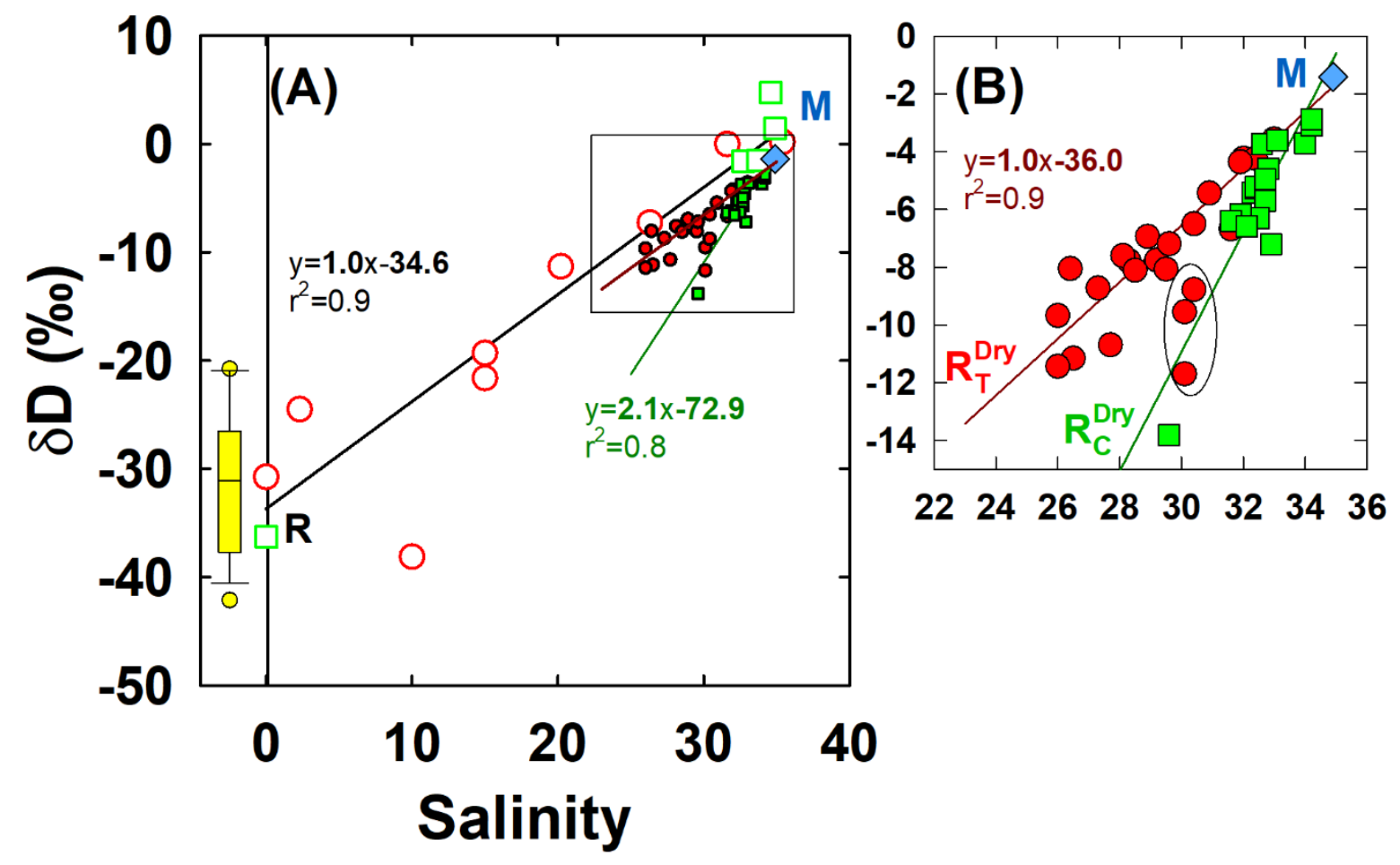

Figure 3: (A) $\delta D-S a l i n i t y$ biplots of all waters collected from the Coco (green symbols), Temala (red symbols) and the box plot of four rivers in the Southeast (yellow, salinity $=0$, see legend of Figure 2 for more details). Samples collected in the mangrove forests (full red and green symbols), across the estuaries (open red and green symbols) and the marine endmember (blue diamond) are also shown. A zoom in the Coco and Temala system during dry season is provided in panel (B). Their respective regression lines are shown in red (Temala) and green (green) while the black regression line represents all samples from Temala and Coco estuaries. The regression for Temala River excludes the data (encircled in B) that are observed on the Coco River regression lines. See text for justification. 

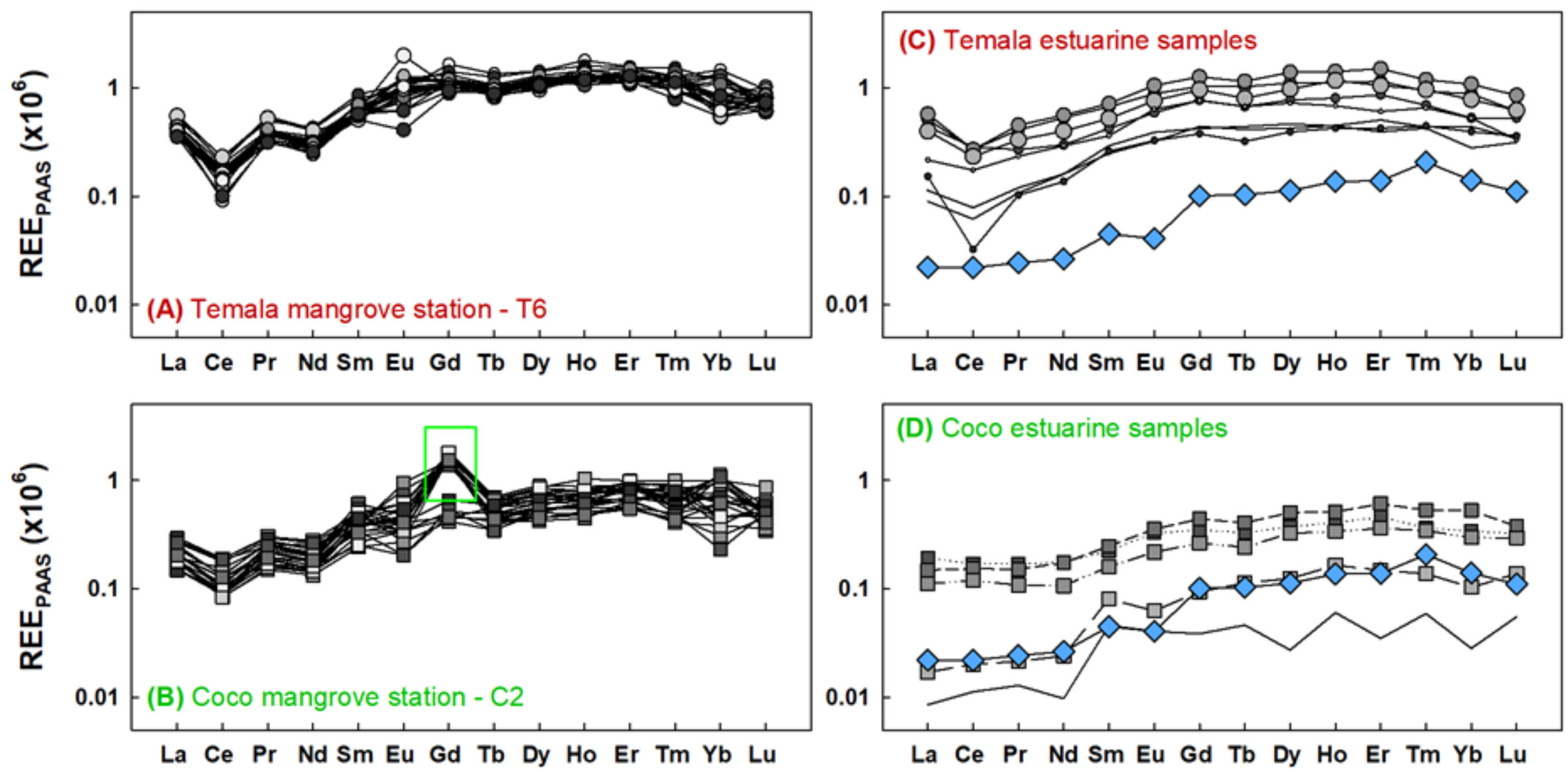

Figure 4: Rare earth element patterns in the waters of the mangrove stations (T6 and C2) at Temala (A) and Coco (B), and across the estuarine mixing of Temala (C) and Coco (D). The blue diamonds show the REE patterns in the marine endmember. The gray intensity of the symbols in panels A and B is associated with the 24-h time-series (black symbols corresponding to the first sampling). The symbol size in panels C and D reflect the salinity (small symbols reflecting freshwater). The green rectangle in B demarks Gd anomalies observed in Coco River water. 

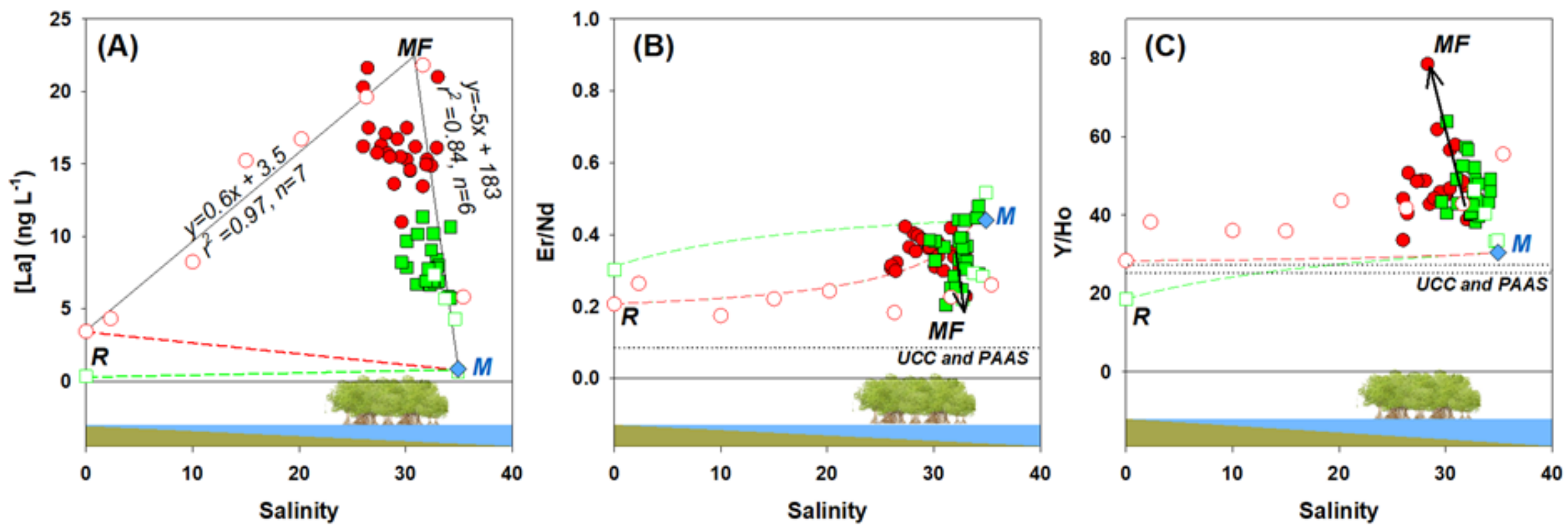

Figure 5: Variations of La concentrations (A), Er/Nd (B) and $\mathrm{Y} / \mathrm{Ho}(\mathrm{C})$ ratios as the function of salinity at Temala (red symbols) and Coco (green symbols). Samples in the mangrove forests are shown by full symbols while estuarine samples are presented as open symbols. The blue diamond symbols represent the marine endmember. The horizontal dotted lines show the values in the Upper Continental Crust (UCC) and PAAS shale. The dotted green and red lines are conservative mixing line for Coco and Temala estuaries, respectively. 


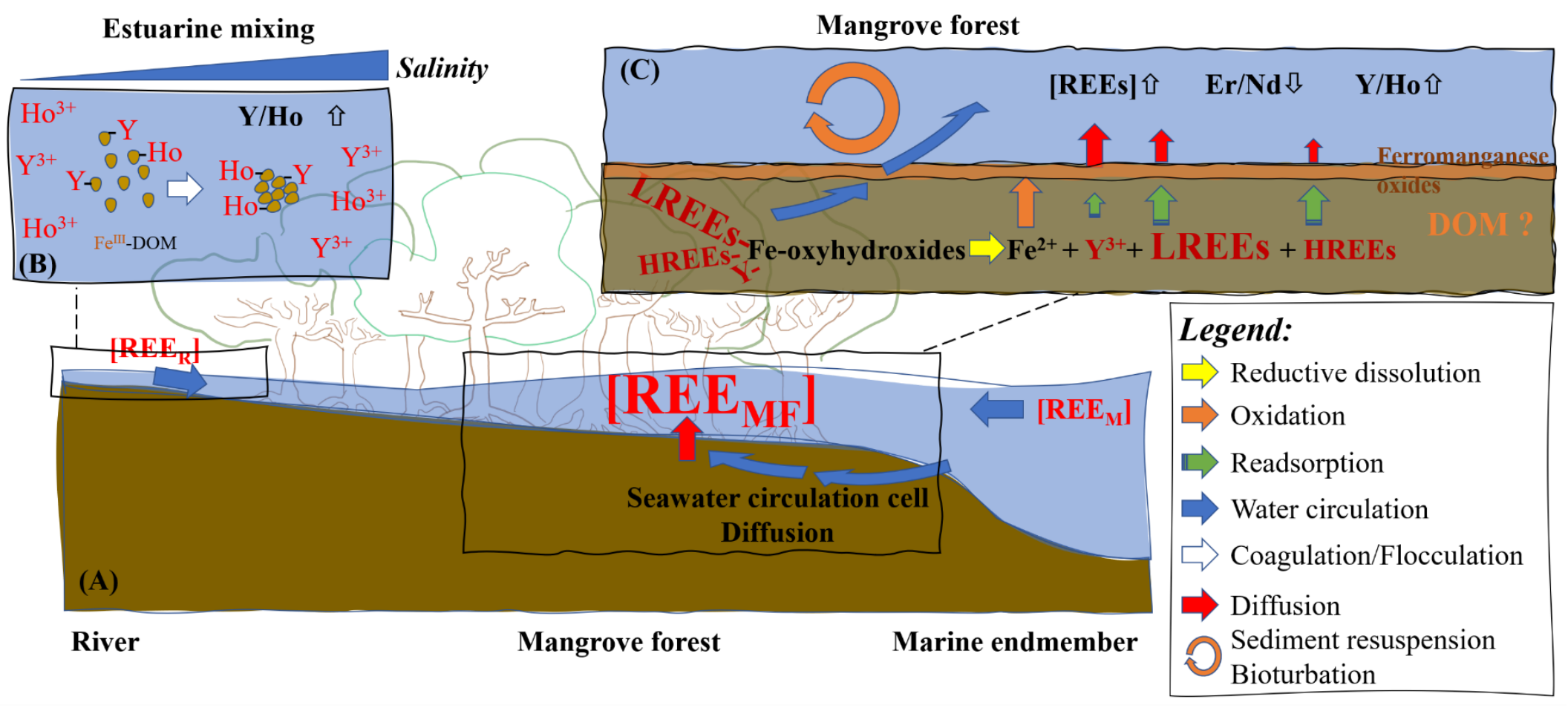

Figure 6: Schematic represention of the REE cycle in tropical mangrove-dominated estuaries (A). Panels (B) and (C) provide a zoom into the mechanisms occuring across the estuarine mixing and within the mangrove forest, respectively. In (B), the flocculation of either dissolved organic Fe $\mathrm{F}^{\mathrm{III}}$ complexes ( $\left.\mathrm{Fe}^{\mathrm{III}}-\mathrm{DOM}\right)$ or colloidal particles is presented. 
Table 1: Variations in the physical-chemical properties of water collected over a 24-hour cycle in the dry season in the Temala (T6) and Coco (C2) mangrove forest.

\begin{tabular}{ccccccc}
\hline \multirow{2}{*}{ Parameters } & \multicolumn{2}{c}{ Temala $(\mathbf{n = 2 4})$} & \multicolumn{3}{c}{ Coco $(\mathbf{n = 2 4})$} \\
& Range & Average & SD & Range & Average & SD \\
\hline Temperature & $16.8-17.7$ & 17.3 & 0.2 & $15.5-16.6$ & 16.1 & 0.3 \\
pH & $7.7-7.9$ & 7.8 & 0.1 & $7.6-8.0$ & 7.7 & 0.1 \\
Salinity & $26.0-33.0$ & 29.5 & 2.1 & $29.6-34.2$ & 32.3 & 1.2 \\
\hline
\end{tabular}

Table 2: Summary of the $\delta \mathrm{D}-\mathrm{S}$ and $\delta^{18} \mathrm{O}-\mathrm{S}$ relationships in the Coco and Temala rivers during rain and dry seasons. Values in brackets show the $\mathrm{r}^{2}$ values. The stable water isotope compositions of the Coco and Temala endmembers $\left(\delta \mathrm{D}_{\mathrm{i}}\right.$ and $\left.\delta^{18} \mathrm{O}_{\mathrm{i}}\right)$ were calculated by the extension of the $\delta \mathrm{D}-\mathrm{S}$ and $\delta^{18} \mathrm{O}-\mathrm{S}$ relationships. For the Southeastern rivers and the marine endmembers, the $\delta \mathrm{D}_{\mathrm{i}}$ and $\delta^{18} \mathrm{O}_{\mathrm{i}}$ values were calculated as the average of all river samples with salinity $=0$ and the values recorded at station $\mathrm{M}$, respectively. For the See text for more details.

\begin{tabular}{|c|c|c|c|c|c|c|}
\hline & Endmembers & $\begin{array}{c}\delta D-S \\
\text { relationship } \\
\end{array}$ & $\begin{array}{c}\delta^{18} \mathrm{O}-\mathrm{S} \\
\text { relationship } \\
\end{array}$ & $\delta D_{i}(\%)$ & $\begin{array}{c}\delta^{18} O_{i} \\
(\% o) \\
\end{array}$ & $\begin{array}{c}\text { d-excess } \\
(\%) \\
\end{array}$ \\
\hline \multirow{2}{*}{$\begin{array}{l}\text { Mangrove } \\
\text { stations - } \\
\text { Dry } \\
\text { season }\end{array}$} & $\operatorname{Coco}(n=17)$ & $\begin{array}{c}y=2.1 x-72.9 \\
(0.8)\end{array}$ & $\begin{array}{c}y=0.2 x-9.9 \\
(0.6)\end{array}$ & $-72.9 \pm 8.9$ & $-9.9 \pm 1.7$ & $15.8 \pm 1.3$ \\
\hline & $\begin{array}{l}\text { Temala } \\
(n=19)\end{array}$ & $\begin{array}{c}y=1.0 x-36.0 \\
(0.9)\end{array}$ & $\begin{array}{c}y=0.2 x-8.4 \\
(0.6)\end{array}$ & $-36.0 \pm 2.8$ & $-8.4 \pm 1.2$ & $15.9 \pm 2.9$ \\
\hline \multirow{2}{*}{$\begin{array}{l}\text { Estuarine } \\
\text { stations - } \\
\text { Rain } \\
\text { season }\end{array}$} & $\begin{array}{l}\text { Temala and } \\
\text { Coco }(n=15)\end{array}$ & $\begin{array}{c}y=1.0 x-34.6 \\
(0.9)\end{array}$ & $\begin{aligned} y= & 0.2 x-5.0 \\
& (0.9)\end{aligned}$ & $-34.6 \pm 1.9$ & $-5.0 \pm 0.4$ & $0.4 \pm 5.8$ \\
\hline & Marine $(\mathrm{n}=1)$ & & & $-1.6 \pm 0.2$ & $-2.1 \pm 0.2$ & \\
\hline $\begin{array}{l}\text { Freshwater } \\
\text { stations }\end{array}$ & $\begin{array}{l}\text { Southeastern } \\
\text { rivers }(n=14)\end{array}$ & & & $-31.2 \pm 6.2$ & $-5.8 \pm 1.0$ & \\
\hline
\end{tabular}


Table 3: The fluxes $\left(R_{i}^{e f f .}, \mathrm{kg} / \mathrm{yr}\right)$ of REEs and Y from the two mangrove systems in New Caledonia (NC) and the extrapolation toward the global flux (ton, or Mg per year).

\begin{tabular}{cccc}
\hline \multicolumn{4}{c}{$\begin{array}{c}\text { Annual fluxes from } \\
\text { mangroves in NC }\end{array}$} \\
& Temala & Coco & \\
\hline Y & $16.1 \pm 4.6$ & $6.1 \pm 1.3$ & $42.1 \pm 21.2$ \\
La & $6.2 \pm 1.2$ & $2 \pm 0.6$ & $14.8 \pm 7.6$ \\
Ce & $6.4 \pm 1.7$ & $3.9 \pm 1.3$ & $22.8 \pm 14$ \\
Pr & $1.1 \pm 0.3$ & $0.4 \pm 0.1$ & $3.0 \pm 1.5$ \\
Nd & $5.5 \pm 1.1$ & $1.8 \pm 0.4$ & $13.3 \pm 5.6$ \\
Sm & $1.2 \pm 0.2$ & $0.4 \pm 0.1$ & $2.9 \pm 1.4$ \\
Eu & $0.3 \pm 0.1$ & $0.1 \pm 0$ & $0.8 \pm 0.7$ \\
Gd & $1.6 \pm 0.4$ & $0.6 \pm 0.3$ & $4.2 \pm 3.3$ \\
Tb & $0.3 \pm 0$ & $0.1 \pm 0.03$ & $0.6 \pm 0.3$ \\
Dy & $1.8 \pm 0.4$ & $0.6 \pm 0.2$ & $4.5 \pm 2.7$ \\
Ho & $0.4 \pm 0.1$ & $0.1 \pm 0$ & $1.0 \pm 0.6$ \\
Er & $1.1 \pm 0.3$ & $0.5 \pm 0.2$ & $3.1 \pm 1.8$ \\
Tm & $0.1 \pm 0.03$ & $0.1 \pm 0.02$ & $0.4 \pm 0.3$ \\
Yb & $0.8 \pm 0.3$ & $0.4 \pm 0.2$ & $2.4 \pm 2.5$ \\
Lu & $0.1 \pm 0.03$ & $0.05 \pm 0.01$ & $0.3 \pm 0.2$ \\
\hline
\end{tabular}

